\title{
Usefulness of four hydrological models in simulating high-resolution discharge dynamics of a catchment adjacent to a road
}

Z. Kalantari ${ }^{1}$, P.-E. Jansson ${ }^{1}$, J. Stolte ${ }^{2}$, L. Folkeson ${ }^{1}$, H. K. French ${ }^{3}$, and M. Sassner ${ }^{4}$

${ }^{1}$ Department of Land and Water Resources, Royal Institute of Technology/KTH, 10044 Stockholm, Sweden

${ }^{2}$ Norwegian Institute for Agricultural and Environmental Research, Bioforsk, Soil and Environment division, 1432 Ås, Norway

${ }^{3}$ Department of Plant and Environmental Sciences, Norwegian University of Life Sciences, 1432 Ås, Norway

${ }^{4} \mathrm{DHI}$ Sverige AB, 11129 Stockholm, Sweden

Received: 8 March 2012 - Accepted: 6 April 2012 - Published: 19 April 2012

Correspondence to: Z. Kalantari (zahrak@kth.se)

Published by Copernicus Publications on behalf of the European Geosciences Union.

Usefulness of four hydrological models

Z. Kalantari et al.

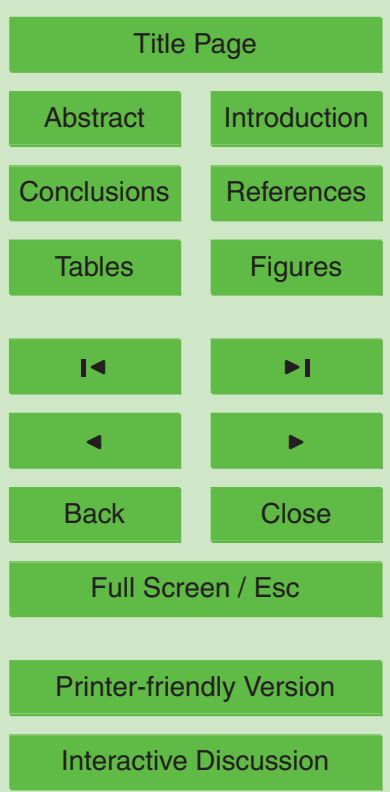




\section{Abstract}

Four hydrological models (LISEM, MIKE SHE, CoupModel and HBV) were compared with respect to their capability to predict peak flow in a small catchment upstream of a road in SE Norway on an hourly basis. All four models were calibrated using hourly 5 observed streamflow. Simulated and observed discharge generated during three types of hydrological situations characteristic of winter/spring conditions causing overland flow were considered: snowmelt, partially frozen soil and heavy rain events. Using parameter sets optimised for winter/spring conditions, flows simulated by HBV coupled with CoupModel were comparable to measured discharge from the catchment in corresponding periods. However, this combination was best when all the parameters were calibrated in HBV. For ungauged basins with no real-time monitoring of discharge and when the spatial distribution is important, MIKE SHE may be more suitable than the other models, but the lack of detailed input data and the uncertainty in physical parameters should be considered. LISEM is potentially capable of calculating runoff from small catchments during winter/spring but requires better description of snowmelt, infiltration into frozen layers and tile drainage. From a practical road maintenance perspective, the usefulness and accuracy of a model depends on its ability to represent site-specific processes, data availability and calibration requirements.

\section{Introduction}

One of the effects of accelerating climate change is an increase in the frequency of extreme weather events in various parts of the world (Schneider et al., 2007; Green Paper EU, 2007). In Scandinavia, climate change is expected to put increasing strain on the road infrastructure system. More frequent extreme precipitation events and floods, as well as landslides and changes in the frequency and duration of snowmelt periods, will probably lead to greater road damage, more frequent road closures and even road constructions being washed away (Green Paper EU, 2007). In addition to extreme flood
HESSD

$9,5121-5165,2012$

Usefulness of four hydrological models

Z. Kalantari et al.

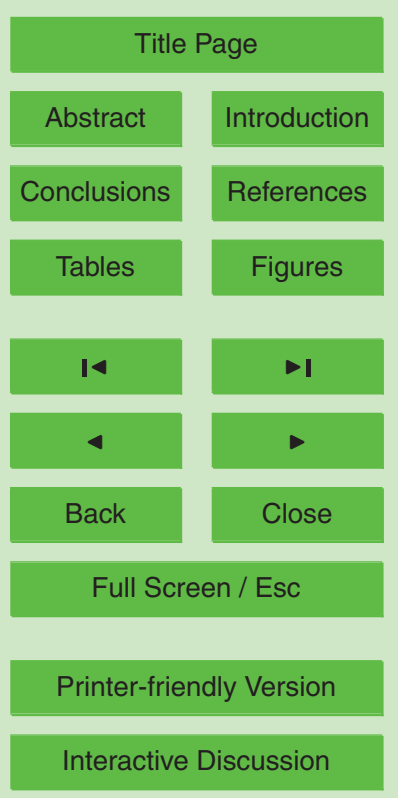

Interactive Discussion 
events, the risk of elevated groundwater levels is an important factor to consider. In some cases the retention capacity of the soil will be decreased due to increased water content, and road life will be shortened as a consequence (Saara and Saarenketo, 2006). Stronger demands will therefore be placed on the function of road drainage 5 systems. Road closures not only have local consequences but also distort the transport system and therefore affect societal functions on a broader scale.

Hydrological models can improve our understanding of how weather events influence catchment hydrology (Jin et al., 2010). Such models can be used to quantify catchment responses to weather extremes and assess their impacts on peak flows 10 (e.g. Stolte et al., 2005). However, limitations of different models with respect to the processes described generate uncertainties regarding the system responses provided by the models.

A hydrological model includes generic categories of geological, hydrological and geographical attributes based on data from available maps and databases. These data can mainly be used to simplify and manage spatially distributed information (Maxe and Johansson, 1998a,b; Stejmar Eklund, 2002). Compared with field investigations, mathematical simulation models provide a rapid and cheap method to obtain realistic outcomes of changes in land use and climate conditions and are therefore frequently used for both research and management purposes. However, the need for measured data for improving and evaluating models is evident (Silberstein, 2006).

For rainfall-runoff modelling applications in catchments near a road drainage construction, a wide variety of hydrological models are available.

To choose between models, a number of criteria are considered in view of the specific expectations defined by the aim of project: (i) model availability; (ii) model performodels had to be applicable to catchments subject to winter conditions with frost, snow and frozen soil; and (vi) the models had to be previously tested or used in practical applications.

\section{HESSD}

$9,5121-5165,2012$

Usefulness of four hydrological models

Z. Kalantari et al.

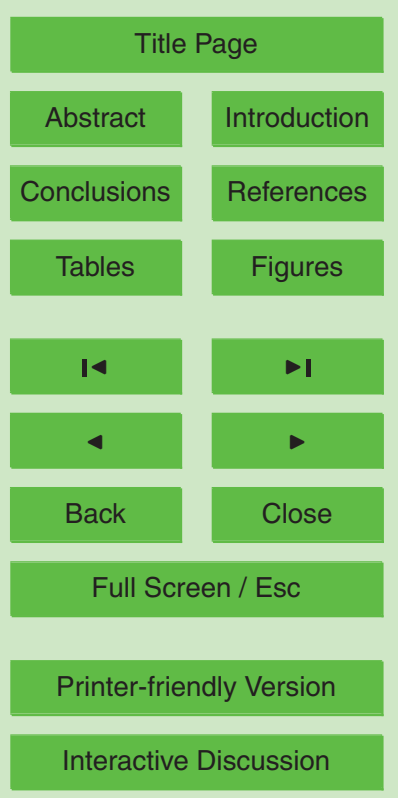


To avoid damage to road constructions, much could be gained if the intensity and duration of peak flows affecting the road drainage system could be simulated and the road drainage structure designed and dimensioned properly. In order to define an effective dimensioning guideline for road drainage constructions, road maintenance authorities need improved modelling tools to predict overland flow in catchments adjacent to roads.

The sequence of frozen and non-frozen soil conditions and transition periods between these is important for the rate of water infiltration into soils in cold regions (Hayashi et al., 2003). The occurrence of snowmelt during rain events is also particularly important and may have a significant impact on runoff volume.

10 There have been numerous studies comparing the performance of different types of hydrological models (Loague and Vander Kwaak, 2002; Gurtz et al., 2003; Deelstra et al., 2010). Deelstra et al. (2010) compared five different types of hydrological models for the area in south-east Norway used in the present study. The results showed good agreement between measured and simulated values when integrating the results over integrated over longer periods. However, efforts have to be made to obtain improved results on a daily and hourly basis, especially as models are potentially useful tools in assessing the possible consequences of climate change on peak discharge. The general aim of the present study was to evaluate the performance of a selection of

\section{drainage structure on an hourly basis. Specific aims were to:}

- identify the capability and usefulness of models of differing degrees of complexity in simulating discharge situations;

- compare the responses of the selected models to three characteristic types of hydrological events with different runoff generation mechanisms: snowmelt, partially frozen soil conditions, and heavy rain events.

Results from this study will be used to help select the best model to simulate runoff near roads. This will facilitate the choice of monitoring methods, provide a firmer basis for

\section{HESSD}

9, 5121-5165, 2012

\section{Usefulness of four hydrological models}

Z. Kalantari et al.

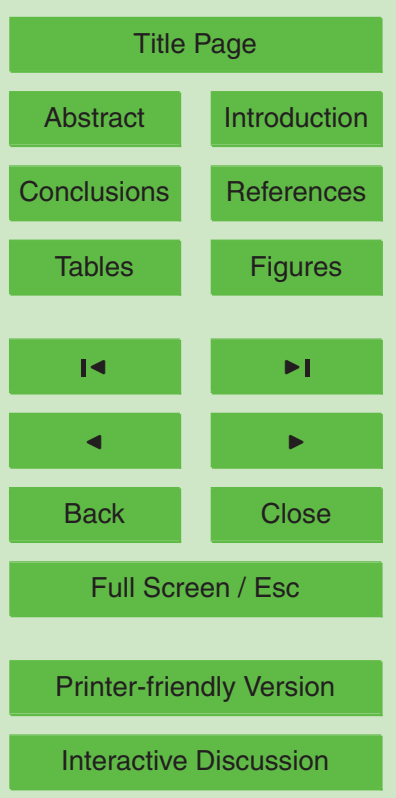

Interactive Discussion 
technical road drainage standards, improve flood prevention measures and ultimately reduce the negative impacts of extreme weather events near roads.

\section{Materials and method}

The approach comprised six steps. These were: (1) selection of a study area with avail5 able meteorological data sets onto which the models could be applied; (2) selection of hydrological models according to the stated criteria; (3) selection and characterisation of meteorological data to compare the selected models; (4) determination of the ability of the models to simulate hourly discharge series using available meteorological data from different weather conditions; (5) calibration of the models on timing, peak levels 10 and total runoff and comparison of their ability to describe various hydrological processes; and (6) analysis of runoff simulated by the models during the three characteristic types of hydrological events chosen.

\subsection{Study area}

The search for a study area was guided by the following criteria: (i) an area with climate conditions similar to those in large parts of Scandinavia; (ii) an area comprising both forest and open land; (iii) an area subject to previous hydrological investigations using well-documented hydrological models; and (iv) availability of good background data.

The Skuterud catchment near Ås, approx. $30 \mathrm{~km}$ SE of Oslo, SE Norway, met all four criteria and was selected for application of the four models. This catchment comprises $2.72 \mathrm{~km}^{2}$ of agricultural land (mostly used for grain, potato and ley crops), $1.29 \mathrm{~km}^{2}$ of forest and $0.49 \mathrm{~km}^{2}$ of urban area. The main soil type is marine silty clay loam with some marine sand and moraine deposits (Deelstra et al., 2005). The annual average temperature for Ås is $5.3^{\circ} \mathrm{C}$, with a minimum measured monthly average temperature of $-4.8^{\circ} \mathrm{C}$ in January/February and a monthly average maximum of $16.1^{\circ} \mathrm{C}$ in July. 25 The annual average precipitation is $785 \mathrm{~mm}$, with a minimum of $35 \mathrm{~mm}$ in February

\section{HESSD}

$9,5121-5165,2012$

Usefulness of four hydrological models

Z. Kalantari et al.

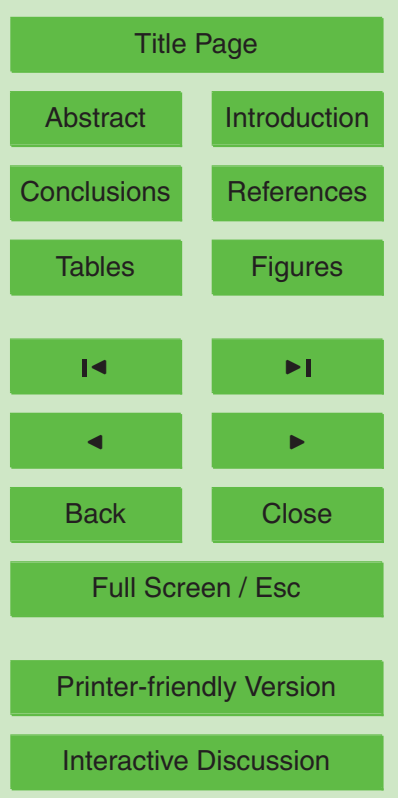


and a maximum of $100 \mathrm{~mm}$ in October. Meteorological data were obtained from the IMT meteorological station (Department of Agricultural Engineering, Norwegian University of Life Sciences) (Thue-Hansen and Grimenes, 2009). The station is located about $2 \mathrm{~km}$ from the study site, at a comparable location in terms of elevation and land 5 use (open landscape). Annual potential evapotranspiration (PET) at this station ranges from $1349 \mathrm{~mm} \mathrm{yr}^{-1}$ (1990) to $1039 \mathrm{~mm} \mathrm{yr}^{-1}$ (2008), with an average of $1077 \mathrm{~mm} \mathrm{yr}^{-1}$ or $3 \mathrm{~mm}$ day $^{-1}$ (Thue-Hansen and Grimenes, 2009). All the arable land is system-drained with drain pipes at $80 \mathrm{~cm}$ depth below the soil surface at $10 \mathrm{~m}$ spacing.

\subsection{Modelling tools and numerical flow models}

10 A number of models are available for modelling discharge and water flow processes in a small catchment. Covering part of the hydrological cycle, the hydrological models of interest here describe water movement from precipitation to runoff (Fig. 1).

Hydrological models can be classified in different ways (e.g. Clarke, 1973; O'Connell, 1991; Wheater et al., 1993; Singh, 1995). Rainfall-runoff models are commonly classified as being lumped or distributed with respect to the spatial and temporal scales. They can also be classified as being based on physical principles or simplified empirical concepts. Stochastic and deterministic frameworks can be combined when considering both the model parameters and input variables. In addition to the classification into stochastic, empirical and physically-based models, models can be further divided into continuous and event-based. The latter produce detailed results for a single event but need accurate independent estimates of initial conditions. An advantage is their ability to use small time steps in the calculation. With continuous models covering a longer period of time, the dynamic factors affecting overland runoff generation can be introduced and analysed more clearly (Tan et al., 2005) without the strong dependence on 25 initial conditions. However, these models can be more uncertain because of the many hydrological processes governing the hydrological conditions in a certain area.

Models are associated with a range of uncertainties, which can be grouped into: (i) model structure uncertainty (to be considered as the simplification of the basic

\section{HESSD}

$9,5121-5165,2012$

Usefulness of four hydrological models

Z. Kalantari et al.

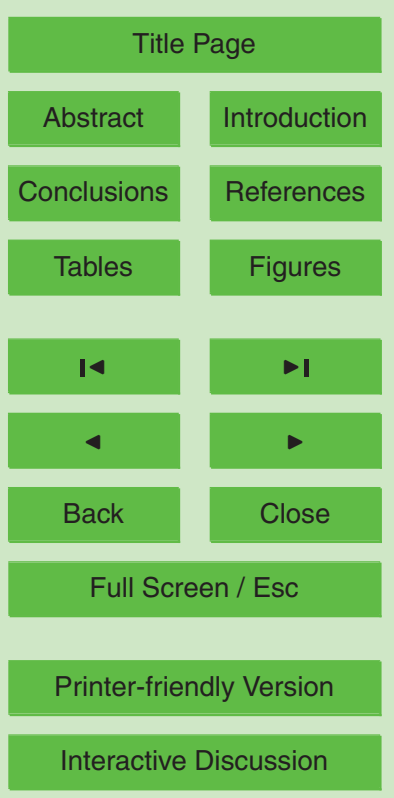

Interactive Discussion 
setup of equations); (ii) parameter uncertainty; and (iii) forcing dynamic input uncertainty (Beven, 2000).

Our search for hydrological models resulted in the selection of four models that met the stated criteria. The models, greatly differing in structure and input requirements, 5 were LISEM, MIKE SHE, CoupModel and HBV. LISEM and CoupModel are widely used and have been validated for different winters (Kværnø and Deelstra, 2003; Kværnø and Stolte, 2012). MIKE SHE is applicable on spatial scales ranging from a single soil profile to large regions including different landscapes (Graham and Butts, 2005). The HBV model is used by the Norwegian Water Resources and Energy Directorate and by 10 the Swedish Meteorological and Hydrological Institute (SMHI).

\subsubsection{LISEM}

LISEM, The LImburg Soil Erosion Model (Jetten and De Roo, 2001) is a spatially distributed, physically based model which simulates hydrology and sediment transport during and immediately after a single rainfall event on a catchment scale. The model 5 was originally developed to test the effect of grass strips and other soil conservation measures on soil loss. The basic processes incorporated in the model are rainfall, interception, surface storage in micro-depressions, infiltration, vertical movement of water in the soil, overland flow, channel flow, detachment by rainfall and throughfall, transport capacity and detachment by overland flow. Also included is the influence of compaction 20 (e.g. by tractor wheeling), small paved roads and surface sealing, losses of phosphorus, nitrate and ammonium in solution and suspension, and gully formation.

The catchment under study has been divided in grid cells of equal sizes (in this study $10 \mathrm{~m}$ ). For each grid cell for every time step, rainfall and interception by plants are calculated, after which infiltration and surface storage are subtracted to give net runoff. 25 Subsequently, splash and flow erosion and deposition are calculated using the stream power principle. The stream power is calculated as water velocity $\times$ slope, and is used to calculate the transport capacity of overland flow (Jetten and De Roo, 2001). Water

\section{HESSD}

$9,5121-5165,2012$

Usefulness of four hydrological models

Z. Kalantari et al.

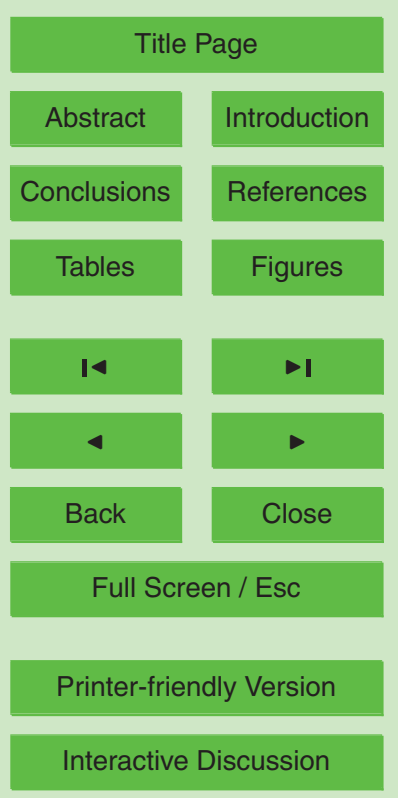

Interactive Discussion 
and sediment are routed to the outlet with a kinematic wave procedure. Infiltration can be calculated with various sub-models, according to the data availability.

LISEM uses rainfall intensities (alternatively snowmelt intensity) per time interval as the only driving variable. Data from multiple rain gauges can be used for creating spa5 tially distributed rainfall. The rainfall is added to the current water height in each grid cell, taking slope angle into consideration. Interception by vegetation is simulated by regarding the canopy as a simple storage.

Infiltration can be calculated by different sub-models depending on the data availability, objective of the simulation and modeller's level of experience. In this study, a finite 10 difference solution of the Richards' equation has been used. Infiltration and soil water flow in the soil profile are simulated by solving Richard's equation, which combines Darcy's law and the continuity equation:

$\partial \theta / \partial t=(\partial[K(h) \times(\partial h / \partial z+1)]) / \partial z$

where $\theta=$ volumetric soil water content $\left(\mathrm{m}^{3} \mathrm{~m}^{-3}\right), K=$ hydraulic conductivity $\left(\mathrm{m} \mathrm{s}^{-1}\right)$, $15 h=$ matric potential $(\mathrm{m}), t=$ time $(\mathrm{s})$, and $z=$ gravitational potential or height above reference level. Values for $\theta$ and $K$ at different $h$ are given in tabular form for each horizon in individual soil profiles linked to a soil profile type map.

For a detailed description of the processes included in LISEM, see http://www.itc.nl/ lisem.

\subsubsection{MIKE SHE}

MIKE SHE is a deterministic, dynamic, physically-based and distributed model which includes all the main processes in the hydrological cycle. The precipitation can either be intercepted by leaves or fall to the ground. The water on the ground surface can infiltrate, evaporate or form overland flow. Once the water has infiltrated the soil, it
HESSD

$9,5121-5165,2012$

Usefulness of four hydrological models

Z. Kalantari et al.

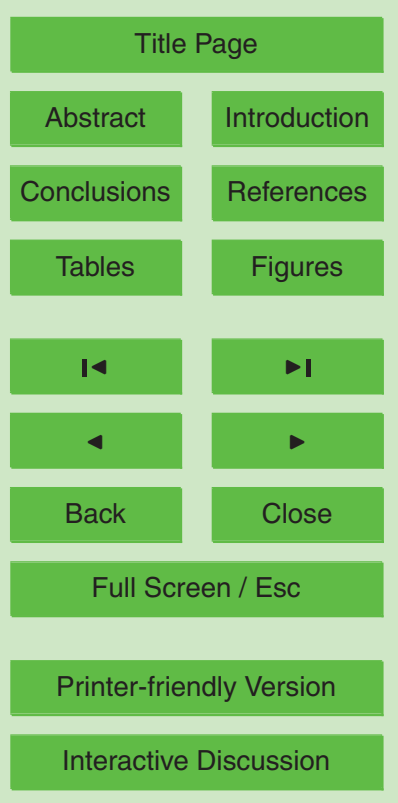


zone. MIKE SHE is fully integrated with a channel-flow code, MIKE 11 (DHI Software, 2008) and consists of the following model components:

- Precipitation (rain or snow).

- Evapotranspiration, including canopy interception, which is calculated according to the principles of Kristensen and Jensen (1975).

- Overland flow, which is calculated with a 2-D finite difference diffusive wave approximation of the Saint-Venant equations, using the same 2-D mesh as the groundwater component. Overland flow interacts with water courses, the unsaturated zone and the saturated (groundwater) zone.

- Channel flow is described through the river modelling component, MIKE 11, which uses the Saint-Venant equations (1-D).

- Unsaturated waterflow is described as a vertical soil profile model that interacts with both the overland flow (through ponding) and the groundwater model (the groundwater level is the lower boundary of the unsaturated zone). Richards's equation model approach has been used in this work to calculate unsaturated water flow.

- Saturated (groundwater) flow is described mathematically by the 3-D Darcy equation and solved numerically by an iterative implicit finite difference technique.

MIKE SHE does not incorporate the influence of frozen soils on runoff generation 20 (Graham and Butts, 2005). For a detailed description of the processes included in MIKE SHE (see Werner et al., 2005; DHI Software, 2008).

\subsubsection{CoupModel}

CoupModel represents a coupled heat and mass transfer model for the soil-plantatmosphere system (Jansson and Karlberg, 2004). CoupModel includes all major

\section{HESSD}

9, 5121-5165, 2012

Usefulness of four hydrological models

Z. Kalantari et al.

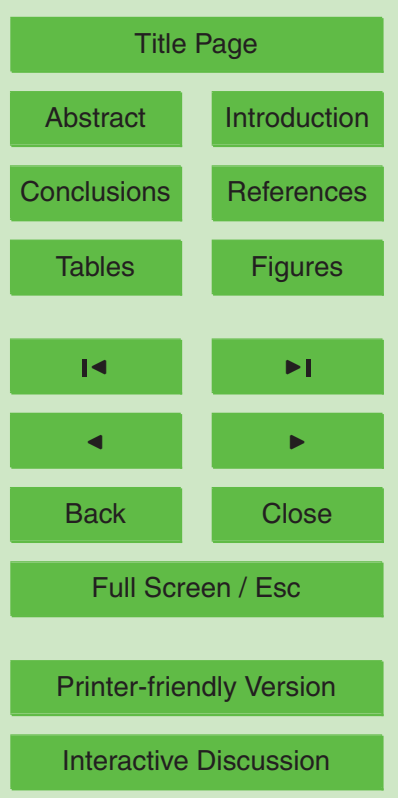

Interactive Discussion 
hydrological processes such as snowmelt, interception of precipitation and evapotranspiration, soil water flows and various boundary conditions. In addition, CoupModel has high flexibility on how to represent the various properties of the hydrological processes by parameters and submodels. The central part of CoupModel uses two cou5 pled differential equations for water and heat flow in the soil, which are solved with an explicit numerical method. The hydrological processes in CoupModel are described by the law of conservation of mass and energy. Flows occur as a result of gradients in water potential (Darcy's law) or temperature (Fourier's law). CoupModel (preceding versions SOIL and SOILN) has been used in different studies for representing wa10 ter balance and dynamics in soil (McGechan et al., 1997), snow dynamics (Gustafsson et al., 2001), infiltration into frozen soil (Stähli et al., 2001), and heat balance of a road surface (Jansson et al., 2006). For a detailed description of CoupModel, see $\mathrm{ftp}: / / w w w . I w r . k t h . s e / C o u p M o d e l / C o u p M o d e l . p d f$.

\subsubsection{HBV}

15 The HBV model (Bergström, 1976, 1992) is a rainfall-runoff model developed at SMHI in the 1970s. It is a simplified summary of the key processes in the hydrological cycle (Fig. 1), which is driven by measured precipitation, temperature and potential evapotranspiration. The model consists of different subroutines such as a snow routine, a soil moisture routine and a runoff routine (Bergström, 1992). The snow routine ac20 counts for snowmelt and snow accumulation. Snowmelt is computed by a degree-day method. In the soil moisture routine, the moisture of a soil box is controlled by precipitation, snowmelt, actual evapotranspiration and soil field capacity. The water in the soil box does not begin to recharge into the groundwater zone until the soil field capacity is reached. Hence groundwater recharge and actual evaporation are functions of ac25 tual water storage in a soil compartment. The runoff generation routine is a response function in which the excess water from the soil moisture storage is transferred into discharge. In the present study, a version of HBV soil module was coupled with modules of vegetation and snow originating from the CoupModel platform.

5130

\section{HESSD}

9, 5121-5165, 2012

Usefulness of four hydrological models

Z. Kalantari et al.

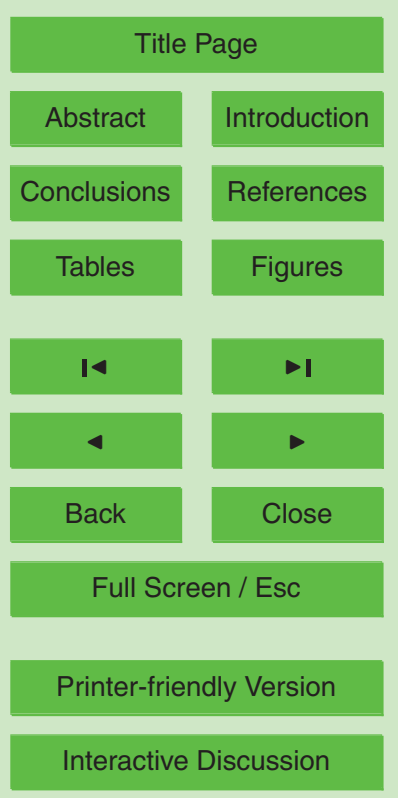

Interactive Discussion 


\subsection{Characteristics of the models}

The main features of the four models are summarised in Table 1, together with the hydrological processes examined in the comparison of these models in this study. The models also differ in complexity and in their differentiation of different flow processes 5 such as surface-subsurface and groundwater runoff, as is listed in Table 1.

The four models were parameterised, calibrated and validated and compared with respect to: (i) aggregation level (time and space); (ii) representation of the hydrological processes; (iii) data and parameters required; (iv) initial and boundary conditions; (v) methods for calibration; and (vi) accuracy of the calculated versus measured hydro10 graph at the catchment outlet.

\subsection{Input data}

The input data required to run the LISEM model for the Skuterud area were taken from Deelstra et al. (2005). The (un)saturated conductivity values for the soils were taken from Kværnø and Deelstra (2003). A soil profile of $1 \mathrm{~m}$ depth was assumed in 15 the calculations, with a $25 \mathrm{~cm}$ thick frozen layer assumed to form the upper layer of the soil profile. We prepared all maps in the GIS programme PCRaster (Wesseling et al., 1995), using as basis a digital elevation model (DEM, $10 \times 10 \mathrm{~m}$ resolution), land use map, soil map (map scales 1:5000) and stream map. The DEM for the Skuterud catchment was made from a topographical map with $1 \mathrm{~m}$ contour lines in ArcMap version 9.3. Digital land use and soil maps were available from the Norwegian Forest and Landscape Institute, and a channel map was taken from the topographical map of the area. The soil map covers approximately $94 \%$ of the arable land, while no soil map exists for the other land use types. A geological map was used to determine the superficial deposits in the missing areas. The vegetation maps were derived from the land use peatland and arable land. The DEM was used to create maps for slope gradients and drainage direction. The soil map combined with the land use map was used to create

\section{HESSD}

9, 5121-5165, 2012

Usefulness of four hydrological models

Z. Kalantari et al.

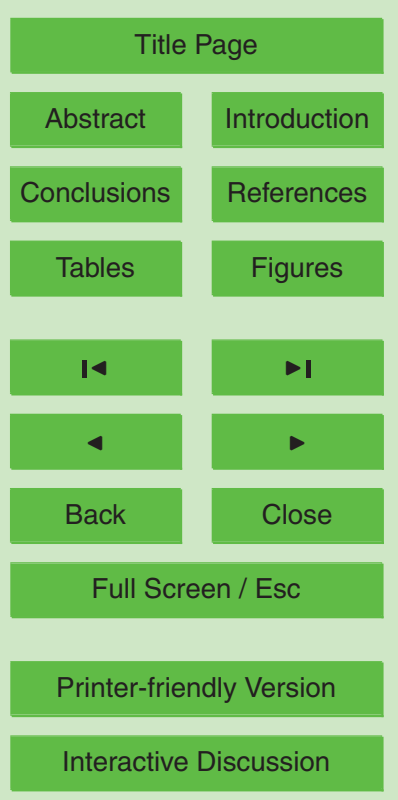


the profile map, i.e. the map with unique soil profile IDs. This map is linked to a text file containing information about soil profile layer depths and which ID corresponds to which soil hydraulic table. The soil surface and erosion maps were made by assigning values either to the profile map ID or the land use ID. Soil physical characteristics were 5 taken from measured water retention curves extrapolated with Mualem van Genuchten equations to estimate the (un)saturated conductivity characteristic.

Vegetation parameters are used to specify vegetation data for the evapotranspiration calculations and constant values of vegetation parameters for land use data such as Leaf Area Index (LAI) and Root Depth (RD) were used in LISEM. However, plant char10 acteristics are dynamic. For example, LAI values for areas with crops change within seasons of the year. Therefore, the vegetation parameter data were assumed to follow a certain pattern during the year in the other models.

The input data to the MIKE SHE model included data on topography, land use, vegetation, geology, hydrogeology and meteorology for the Skuterud catchment. These data were previously used in setting up the LISEM model. The model was discretised in a $1 \mathrm{~m} \times 1 \mathrm{~m}$ horizontal grid. The topography was used to define the surface of overland flow, i.e. the uppermost surface of the unsaturated and saturated zone. A soil depth map is available for the whole catchment and soil types are assigned via a polygon shape file including six predominant soil types. The dominant soils in the central and level parts are marine silt loam and silty clay loam soils. The texture of the shore deposits is mainly sand and loamy sand. Lighter clay soils such as loam and sandy loam can be found in the transition between marine and shore deposits (Kværnø et al., 2007). For each of these soils, Van Genuchten retention and conductivity curve parameters were specified (MIKE SHE manual). Vertical conductivity of the aquifer influences fluxes through the soil surface and the horizontal conductivity of the saturated soil dominates base flow and peak discharge. These values were determined based on the values used by Kværnø and Deelstra (2003). The meteorology data used in MIKE SHE comprise temperature, precipitation and reference evapotranspiration. The top boundary condition is expressed in terms of the precipitation and reference
HESSD

$9,5121-5165,2012$

\section{Usefulness of four hydrological models}

Z. Kalantari et al.

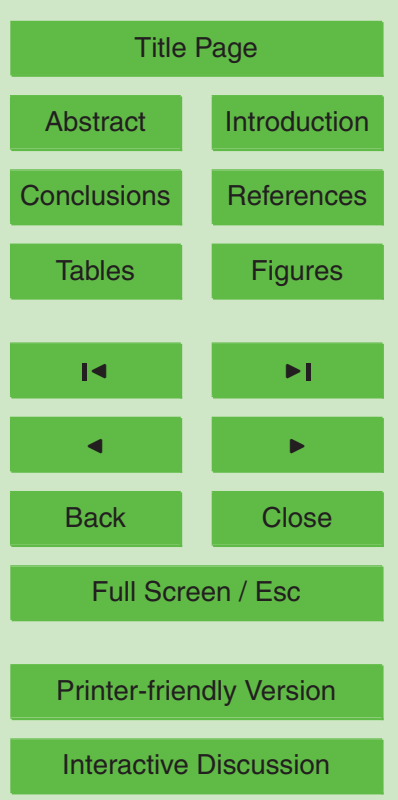

Interactive Discussion 
evapotranspiration. The precipitation is assumed to be uniformly distributed over the model area, and given as time series. In this study, the reference evapotranspiration value was determined by the Penman-Monteith method (Monteith, 1965) for a reference surface. Based on FAO guidelines (Allen et al., 1998), the reference surface is a 5 hypothetical grass surface dependent on climate and can be calculated from weather data Vegetation parameters were used to specify vegetation data for the actual evapotranspiration calculations. Because of seasonal changes, the vegetation may have different crop stages. For each crop stage, the vegetation parameters LAI, RD and crop coefficient $\left(K_{\mathrm{c}}\right)$ were specified using values were taken from the MIKE SHE database. 10 The roughness parameter $(M)$ was also specified for the calculation of overland flow. The higher the $M$ value, the faster the water is routed as an overland flow to the nearest river connection, and therefore the peak flow is particularly affected. In the present model, the variations in $M$ were developed using a defined relationship between land use/land cover and values of roughness coefficient from Swain and Decker, the South 15 Florida Water Management District and the US Army Corps of Engineers. The hourly meteorological data used in CoupModel and HBV comprise precipitation, global short radiation, air temperature, wind speed and relative air humidity. CoupModel and HBV use the same driving meteorological variables as the LISEM model. A soil profile of $1 \mathrm{~m}$ was specified in CoupModel using Van Genuchten retention and conductivity curve parameters from Kværnø and Deelstra (2002). The vegetation parameter in Coup Model was the same as the value defined for arable land in MIKE SHE. The HBV model uses the same vegetation model as CoupModel. An overview of main model parameters, methods and values is given in Table 2 .

Using data from the Skuterud catchment, it was possible to analyse the runoff generation mechanisms during three periods, each of which included different types of hydrological events: snowmelt, partially frozen soil and rainfall.

Predictions and observations of discharge were compared and illustrated for the three hydrological periods, 10 January-17 January 2008, 20 November-10 December 2007 and 2-12 November 2007, referred to as period I, II and III.

\section{HESSD}

$9,5121-5165,2012$

Usefulness of four hydrological models

Z. Kalantari et al.

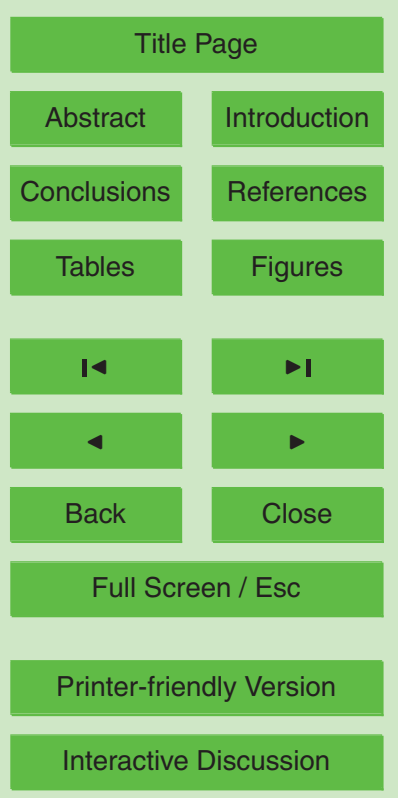

Interactive Discussion 


\subsection{Calibration and setup strategies}

In a lumped conceptual simplified model, parameterisation is normally a more important process following different strategies compared with a model with a specific physical meaning and connection to real geographical boundaries. In a fully distributed 5 physically-based model, only parameters based on independent measurements are considered (Graham and Butts, 2005). The performance of physically-based models is expected to be good without formal calibration procedures when sufficient data are available (Sahoo et al., 2006). However, it is difficult to obtain spatially distributed values of all input parameters for such a model when applied to a detailed catchment scale. As

a consequence, the input parameters need to be simplified and spatially averaged for the selected locations. Due to the discrepancy in scales, measurement errors and lack of data, distributed models will always have uncertainties, just as any mathematical model of real-world environmental conditions. However, the understanding has been that the distributed physically-based models are uncertain because of lack of independent input data. Empirical simplified models, on the other hand, are uncertain due to the lack of consideration of important hydrological processes or the lack of data available for calibration of parameters (Sorooshian and Gupta, 1995; Sahoo et al., 2006; Kværnø and Stolte, 2012).

\subsubsection{Choice of model performance index}

20 The choice of a model performance index is important in order to better understand model errors in simulation and observed data (Beven, 2006). In the present context, the indices chosen were: a coefficient of determination of a linear regression line between simulated and observed discharge data $\left(R^{2}\right)$ and Nash-Sutcliffe simulation efficiency (NSE). Since $R^{2}$ and NSE are independent of the scale of data, they are widely data to observed data (Dawson and Wilby, 2001). The mathematical expression of these statistics is defined by e.g. Nash and Sutcliffe (1970), Draper and Smith (1998)
HESSD

$9,5121-5165,2012$

Usefulness of four hydrological models

Z. Kalantari et al.

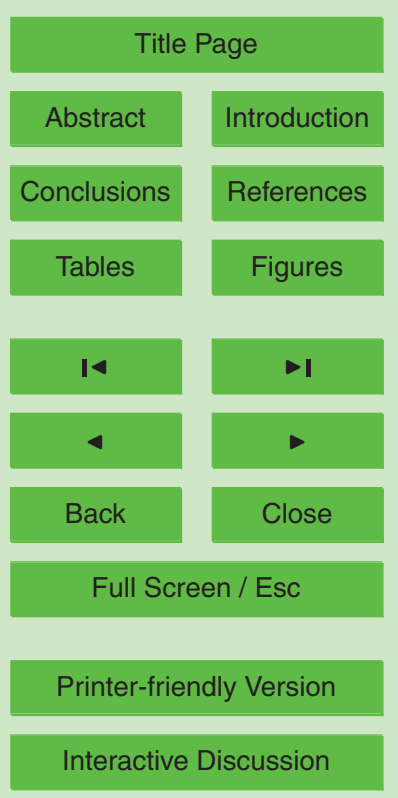


and Everitt (2002). The $R^{2}$ value measures the extent to which the variability in modelled data can explain the variability in observed data using a linear relationship. Zero intercepts and slopes to unity indicate a perfect model. NSE is used to assess the predictive power of models. It considers the ratio between the variance of the modelled data and the variance of the observed data and can vary from $-\infty$ to 1 . An efficiency of NSE $=1$ corresponds to a perfect match between modelled discharge and observed data, i.e. the measured data are identical to simulated. An efficiency of NSE $=0$ indicates that the model prediction is as accurate as the mean of the measured data. Negative values of NSE typically appear when the residual variance between simu10 lated and measured is higher than the measured data variance (Nash and Sutcliffe, 1970; Moriasi et al., 2007).

\subsubsection{LISEM}

A rainfall and snowmelt event on 10 January 2008 was used to calculate the hydrograph. This event took place after a long period of frost that had resulted in a frozen top 15 layer of the soil. This can be seen in Fig. 3, where results of air and soil temperature are presented. From around 18 January, the temperature of the top soil layer started to rise above $0^{\circ} \mathrm{C}$. Calibration of the model results was performed on the measured peak discharge, optimising the saturated conductivity value of the frozen layer. Initially, the saturated conductivity $\left(K_{\mathrm{s}}\right)$ values as presented in Table 3 were used in the calculations. These values were lowered for the first $25 \mathrm{~cm}$ of the soil profile to simulate the effect of frozen soil on the hydraulic conductivity. The calibrated saturated conductivity value for the top $25 \mathrm{~cm}$ of the soil profile was used to calculate the runoff during an event on 13-16 January 2008. This calibration procedure is based on sensitivity analyses of the LISEM model done in other studies (De Roo et al., 1996; Hessel et al., 2003; Stolte et al., 2003; Kværnø and Stolte, 2012). These studies show that for the calibration of the hydrological part of the model apart from the climatological input, the $K_{\mathrm{s}}$ factor is the driving factor.
HESSD

$9,5121-5165,2012$

Usefulness of four hydrological models

Z. Kalantari et al.

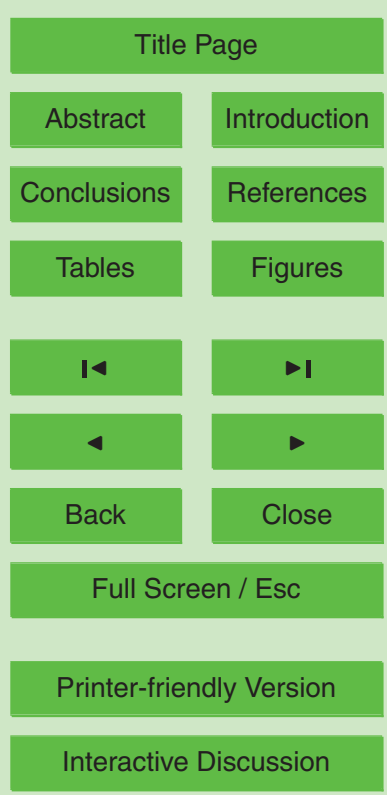




\subsubsection{MIKE SHE}

Calibration of MIKE SHE aimed at finding an optimal value for physically realistic parameters that could simulate the Skuterud catchment as accurately as possible. The model was run for a 16-month simulation period, from January 2007 to 30 April 2008.

5 The calibration was carried out in two steps in a simple intuitive way. The first step was to check numerical instabilities. To acquire better numerical accuracy, time step and numerical interaction criteria were controlled and optimised. In the second step, a simplified tuning of the drainage time constant (leaching coefficient) was applied in order to obtain a better calibrated model for the single event on 10 January 2008. The drainage time constant is the first order coefficient of linear reservoir model for interflow and drains. The time constant determines the velocity of drainage and mainly has an influence on the peak of the hydrograph. The smaller the time, the smaller the peak of the hydrograph (Vásquez et al., 2002). According to DHI (1998), a typical feasible value for the drainage time constant is $\left(1 \times 10^{-7}, 1 \times 10^{-6}\right) \mathrm{s}^{-1}$, which is approximately 15 equivalent to an interval of $(120,10)$ days. Refsgaard (1997) suggested the drainage coefficient of 33 days after calibration of a medium-sized catchment with geology consisting of sand and gravel with few moraine clay layers. For catchments having an upper geological clayey loam layer, a higher drainage coefficient was suggested by Vásquez et al. (2002). On this basis, the drainage time constant for calibration of MIKE SHE in 20 Skuterud catchment was set to $\left(5.5 \times 10^{-7}\right) \mathrm{s}^{-1}$ which was equivalent to an interval of 65 days (Table 2 ).

\subsubsection{CoupModel}

CoupModel was run for the same 16-month simulation period MIKE SHE, i.e. from January 2007 to 30 April 2008. This model was calibrated for the 6-month period from late
HESSD

$9,5121-5165,2012$

Usefulness of four hydrological models

Z. Kalantari et al.

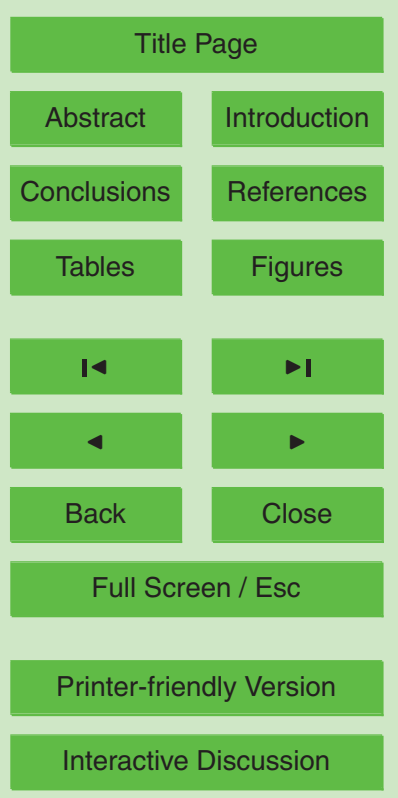
represent the Skuterud catchment, of which 52 were fixed and 17 selected for calibration by specification of a uniform range for each parameter. The parameters selected for 
the calibration were intended to consider different processes for water balance. These included parameters for snow pack, soil evaporation, soil frost, soil water flows, surface water and vegetation. Multiple random realisations of the 17 parameters were set with pre-defined prior boundaries for this model.

5 For each realisation and time series of discharge flow, 1000 runs were simulated based on defined initial boundary conditions and particular parameter sets. The automatic calibration procedure based on Monte Carlo simulation (Beven, 2000) together with a multi-objective criterion were used to calibrate CoupModel. Accepted runs were based on criteria for rejection assuming a threshold value of $R^{2}$ and NSE. By applying 10 the statistical criteria NSE $>0.6$ and $R^{2}>0.6$, the number of accepted runs was 244 . The posterior mean and coefficient of variation $(\mathrm{CV})$ value of parameters based on the accepted runs were compared with the corresponding values from the prior assumptions, based on a uniform distribution. A narrow distribution of posterior parameter values can be considered as a reduced parameter uncertainty.

15 Fifteen of the 17 calibrated parameters showed differences between prior and posterior distributions. Of all the calibrated parameters, MeltCoefGlobRad from the snow pack module and SurfCoef from the surface water module were the most sensitive parameters. The MeltCoefGlobRad parameter stands for the snowmelt coefficient associated with global radiation in the empirical snowmelt function (Jansson and Karlberg, 2004; Mellander et al., 2005). The SurfCoef parameter is the first order rate coefficient used when calculating the surface runoff from the surface pool exceeding the residual storage (the maximum amount that can be stored on the soil surface without causing any surface runoff) (Jansson and Karlberg, 2004).

\subsubsection{HBV}

25 The HBV model was run coupled with vegetation and snow modules originating from the CoupModel platform. Therefore it was run and calibrated during the same period as described for CoupModel. The automatic calibration procedure based on Monte Carlo simulation (Beven, 2000) together with a multi-objective criterion were used in

\section{HESSD}

$9,5121-5165,2012$

Usefulness of four hydrological models

Z. Kalantari et al.

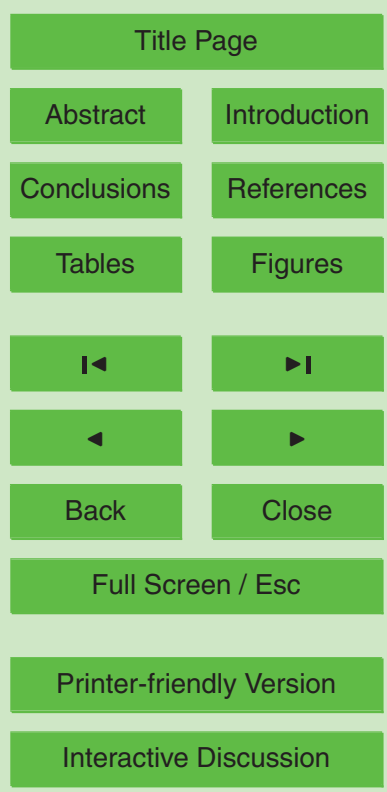

Interactive Discussion 
HBV for a number of random multiple runs (1000 for Skuterud catchment modelling). HBV model included 17 parameters in total. All 17 parameters were selected for the calibration process. Of the 17 parameters, 10 were defined as HBV parameters representing the soil component and 7 originated from the snow and vegetation modules in 5 CoupModel.

The parameter threshold was subjectively defined in the same way as for CoupModel. After considering the statistical criteria NSE $>0.6$ and $R^{2}>0.6$, the number of accepted runs was 614 .

The large number of accepted runs indicated that the prior distribution of selected 10 parameter values was reasonably good. This means that all calibrated parameters influenced the model. However, of all parameters, MeltCoefGlobRad and Discharge Alfa were the most sensitive. Discharge Alfa is a measure of non-linearity for fast flow from the upper response box in HBV (Lindström et al., 1997).

\subsection{Computation time}

All computations were run on a standard personal computer (Quad CPU, 8 GB installed memory and 64-bit operating system). The CoupModel and HBV models including the pre-calculations were set up in 3 days. MIKE SHE needed a longer time to prepare spatially-based parameters and was set up in 2 weeks. At first, the run-time of a single run of CoupModel and HBV was less than 5 minutes and the multi-run $(N=1000)$ on a CPU processor to reduce simulation time. MIKE SHE used a calculation time of $14 \mathrm{~h}$ for each single run. For the LISEM model, about 5 days were needed to set up all parameter input data. Total calculation time for the 11 January calibration run was about $1 \mathrm{~h}$, and for the validation period (13-16 January) about $4 \mathrm{~h}$.

HESSD

$9,5121-5165,2012$

Usefulness of four hydrological models

Z. Kalantari et al.

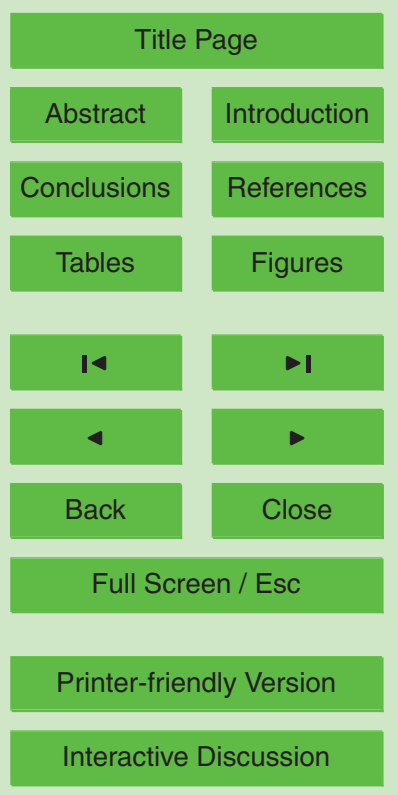




\section{Results}

\subsection{Performance of the models}

HESSD

The LISEM model results were optimised on measured peak discharge and timing. The Manning's $n$ value of the channel was used to optimise for timing and the satu5 rated conductivity $\left(K_{\mathrm{s}}\right)$ value was altered to calculate the peak discharge. Results were graphically interpreted, and $R^{2}$ was calculated on the peak discharge for the total period of 11-17 January 2008.

The performance of MIKE SHE was evaluated using $R^{2}$ for a linear regression line between measured and simulated values and NSE.

10 In CoupModel and HBV, 1000 simulations were run to get the parameter range, thus obtaining a reasonable distribution of output. $R^{2}$ and NSE were used to evaluate simulation performance. These coefficients were chosen as likelihood measures to evaluate the accuracy of both the magnitude and timing of predicted discharge (e.g. Andersen et al., 2001; Beven, 2001; Vásquez et al., 2002; Tague et al., 2004). The correlation be15 tween $R^{2}$ and NSE provides valuable insights regarding the hydrological performance of models across the ensemble of runs. The statistics for the 1000 runs on each of CoupModel and HBV (Fig. 2) showed that NSE was always lower than $R^{2}$, since the models typically failed in simulation of the mean value of runoff.

An NSE equal to $R^{2}$ would indicate a correct mean value of the model. The nearly linear lower border of the point cloud of both plots indicates that both models were able to simulate the same water balance (mean value). The stronger trend of aggregation of points towards the lower line in the case of HBV indicates that more realisations with a proper water balance were obtained for HBV than for CoupModel in this application.

To date, no absolute criteria for judging model performance have been firmly estab25 lished in the literature. According to Moriasi et al. (2007), the calibration performance for hydrological models is considered satisfactory when NSE $>0.5$ and $R^{2}>0.5$. Assuming a criterion of $>0.6$ for both NSE and $R^{2}$, the majority of runs from HBV would be judged as adequately replicating observed discharge. The correlation between $R^{2}$

\section{Usefulness of four hydrological models}

Z. Kalantari et al.

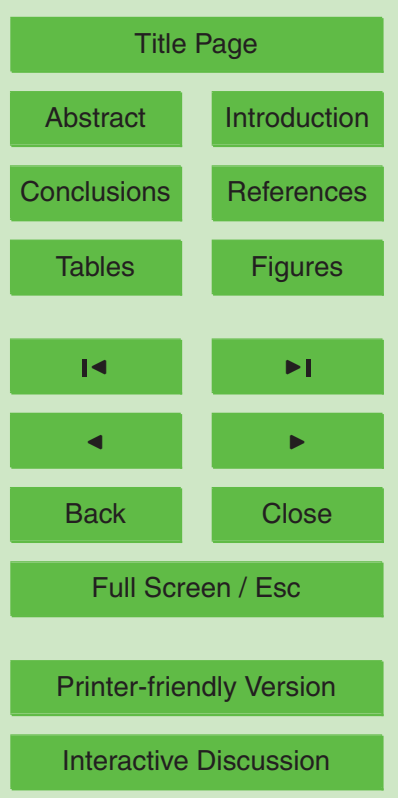


and NSE from HBV mainly fits the 1:1 line, which indicates that the $R^{2}$ dispersion almost equals the NSE dispersion. This means that most of the realisation with the best value of $R^{2}$ was accompanied by the best value for NSE. For instance, the best $R^{2}$ value (0.86) was found in a realisation with a best value for NSE (0.82).

In order to compare the discharge from LISEM, MIKE SHE, CoupModel and HBV models for different periods, the best simulation obtained was chosen. Over the calibration period, the statistics $R^{2}$ and NSE for the best simulated hourly discharge obtained in all models are presented in Table 3.

\subsection{Discharge dynamics}

10 The simulation results from LISEM were only available for period I because discharge for the other periods was most likely caused by subsurface drainage water, a process which is so far not included in the LISEM model. Unfortunately, there were no soil temperature measured data during these three periods for the whole catchment studied. The simulated soil temperature data from CoupModel was used to analyse the runoff 15 generation mechanisms and catchment hydrological responses (Figs. 3, 5 and 7).

During spring snowmelt (period I), as air temperature increased and snowmelt water reached the frozen soil, the simulated temperature of the soil was close to $0^{\circ} \mathrm{C}$. The temperature of frozen soil can remain near $0^{\circ} \mathrm{C}$ because of the fusion energy related to the phase shift (from pore ice to liquid) with very small simultaneous increase in temperature. The soil at a shallow depth $(5 \mathrm{~cm})$ was partially frozen, while the soil at depths of $5-25 \mathrm{~cm}$ was most often only slightly below freezing (Fig. 3). The duration of soil frost and the depth to which the soil was actually frozen are associated with substantial uncertainty, typically related to the variability in the depth and duration of snow and vegetation cover, as well as soil properties. For period II, the soil at shallow depth $(5 \mathrm{~cm})$ was completely frozen according to the model when the air temperature also decreased to below $-5^{\circ} \mathrm{C}$. During these conditions, the snow cover was limited, which also made the soil sensitive to thawing when the air temperature went up.
HESSD

$9,5121-5165,2012$

Usefulness of four hydrological models

Z. Kalantari et al.

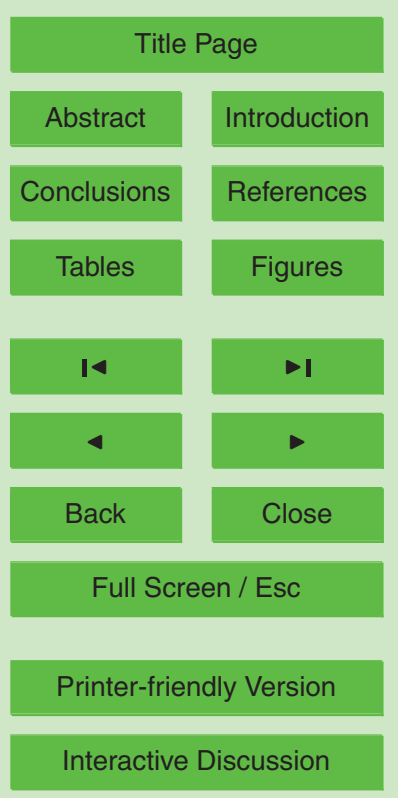

Interactive Discussion 
Period I included snowmelt, partially frozen soil and rain event conditions. Two events in January 2008 were used to evaluate the model performance using a time resolution of one hour. The event on 10 January had a total rainfall of $13 \mathrm{~mm}$ with a maximum intensity of about $8 \mathrm{~mm} \mathrm{~h}^{-1}$. The event on 13-18 January produced $80.6 \mathrm{~mm}$ total rainfall 5 with a maximum intensity of about $15 \mathrm{~mm} \mathrm{~h}^{-1}$, which is equal to a 2 -yr storm according to the Norwegian Meteorological Institute. The Snow Water Equivalent before the event was $2.4 \mathrm{~cm}$ (measurement in the study area on 8 January). The soil temperature at 10 January was -0.5 at $10 \mathrm{~cm}$ depth, -0.3 at $20 \mathrm{~cm}$ and 0.0 at $40 \mathrm{~cm}$ depth (measured at the IMT weather station). The runoff events mostly followed precipitation events The precipitation hyetograph and simulated and observed hydrographs (Fig. 3) indicate that all four models have potential for estimating discharge from a small catchment during a winter sub-period. All of the models were optimised for best performance for the event on 10 January. The LISEM and MIKE SHE models showed a good estimate of 15 the peak discharge for the first measured event, on 11 January.

The results for the second simulated event (13-18 January) showed that the four models differed in their prediction of the dynamics with respect to timing and intensity. The measured discharge on 14 January was not predicted accurately by any of the models, although both CoupModel and HBV simulated an increase in runoff but with 20 a 5-h lag compared with the measurements. The delay in the models can originate from snowmelt, the internal storage capacity for water or the rate of response to increased storage of water in the system. All water in the generation of runoff is from two groundwater compartments in the HBV model, whereas CoupModel represents both a surface pool of water and a continuous series of soil water compartments from which runoff can be generated when soils become saturated. The delay in the simulation of this peak may have a different explanation. Although CoupModel could represent the partially frozen soil condition on 14 January, it was not very successful in simulating the peak flow generated by this phenomenon. This peak was because during frozen soil conditions, snowmelt water cannot infiltrate into the soil to recharge soil moisture
HESSD

$9,5121-5165,2012$

\section{Usefulness of four hydrological models}

Z. Kalantari et al.

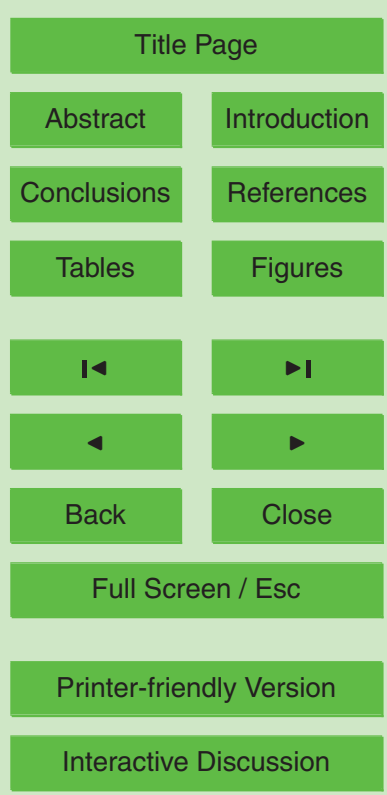

Interactive Discussion 
and instead forms surface water, which has a faster response in the real world than in models which do not include this process. The measured peak on 15 January was not predicted by LISEM. This failure might be caused by the subsurface drainage system not being incorporated into this model. The last measured discharge, on 17 January, 5 was overestimated by LISEM and MIKE SHE.

Errors in discharge are typically described in terms of peak errors, volume errors, mean absolute errors or some kind of correlation coefficient (e.g. the NSE coefficient). The choice depends on the purpose of the model. In the present case, the peak error was considered as being by far the most important parameter. Inter-model comparison 10 of the peak errors (residuals) from seven peaks between 10 and 18 January 2008 (period I) showed that MIKE SHE overestimated the measured intensity of some of the peaks, while CoupModel and HBV underestimated some of the peaks. In some cases, the simpler model (HBV) gave smaller peak errors compared with the more complex MIKE SHE model (Fig. 4).

Period II included frozen soil and rain event conditions. Two events, on 24 November and 1 December 2007, were used to evaluate the performance of the models. The November and December events had a maximum rainfall intensity of about 7 and $10 \mathrm{~mm} \mathrm{~h}^{-1}$, respectively. The predicted discharge from three models (MIKE SHE, CoupModel and HBV) is illustrated in Fig. 5. The discharge hydrograph predicted by all three models shows that the runoff events mostly followed precipitation events. The models were much more similar in this period, although the soil was frozen and only one model accounted for frozen soil.

Period III included non-frozen soil and rain event conditions. Two events, on 5 and 8 December 2007, were used to evaluate model performance, the time resolution being one hour. The rainfall events had a maximum rainfall intensity of about 4.5 and $5 \mathrm{~mm} \mathrm{~h}^{-1}$, respectively. The results from both events in period III showed that three models predicted the dynamics with respect to intensity very differently. MIKE SHE and CoupModel overestimated peak discharge, while HBV underestimated peak discharge (Fig. 6). This period represented conditions close to a simplified hydrological
HESSD

$9,5121-5165,2012$

Usefulness of four hydrological models

Z. Kalantari et al.

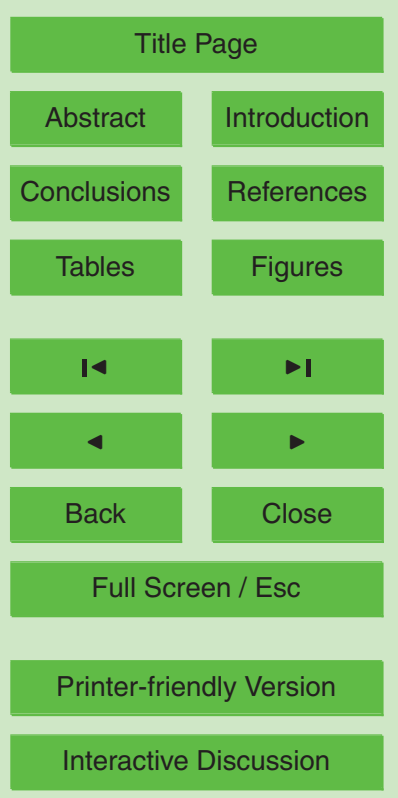

Interactive Discussion 
event without snow and frozen soil. All models also had a more similar way of representing runoff generation from rain to runoff than from snowmelt and frozen soil. This sub-period showed the highest differences in simulated discharge between the models.

HBV simulated much higher actual evapotranspiration than CoupModel, despite the 5 fact that to a large extent they used the same module for evapotranspiration. The evapotranspiration in MIKE SHE was almost equal to zero in all three periods analysed. This means that in periods of high temperature and dry soil conditions in autumn, the evapotranspiration may have an impact on runoff. Forests in particular can have substantial evaporation from intercepted water (Gustafsson et al., 2004). In contrast, the 10 influence of evapotranspiration on runoff was almost negligible during winter months (period I). Unfortunately, there were no actual evaporation data for the catchment studied. However, the large difference in response to rain in the beginning of November indicated that the evapotranspiration process may be of great importance in describing some early peak runoff when the soil is partly saturated.

15 For each model, the residual of simulated discharge during each period was calculated and the distributions of residuals were produced. Inter-model comparison of the percent cumulative distribution functions (CDFs) of model discharge residuals (Figs. 7 to 9) revealed that the slope of the CDF at a residual of zero was an indication of the spread of the distribution, and hence a measure of errors in the model simulations.

20 The errors introduced by CoupModel (Fig. 7, dashed line) were about the same as those introduced by the HBV model (dot-dashed line). The percentage CDFs of MIKE SHE residuals (solid line) and LISEM (dotted line) showed a larger spread, and hence larger errors.

A discharge residual value between -0.3 and +0.3 (10\% of maximum measured discharge) was chosen as an acceptable range. The CDFs of MIKE SHE and LISEM residuals indicated that the runoff volume simulated by these models was underestimated by almost $40 \%$ and $70 \%$, respectively. In contrast, CoupModel and HBV overestimated runoff by $30 \%$ and $20 \%$, respectively. The total amount of discharge was less accurately predicted by models in period I. This might be explained by snowmelt, as the

\section{HESSD}

$9,5121-5165,2012$

Usefulness of four hydrological models

Z. Kalantari et al.

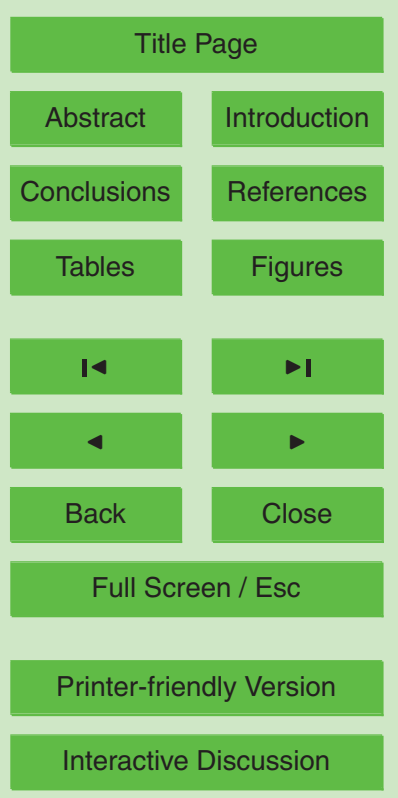

Interactive Discussion 
area was covered by snow during both events studied. Snowmelt was simulated with the same module in CoupModel and HBV, based on global radiation, air temperature and heat flux from the soil. MIKE SHE uses a simpler snow module only considering air temperature. Moreover, melting may not occur exactly at a threshold temperature, 5 e.g. $0^{\circ} \mathrm{C}$, whereas models consider the freezing point and melting point as the same temperature $\left(0^{\circ} \mathrm{C}\right)$. Therefore, models may underestimate or overestimate the amount of snowfall and rainfall, as well as snowmelt water.

MIKE SHE considers freezing and melting of snow on the soil surface but it does not consider the effect of temperature on water infiltration into the soil profile. Due to 10 partially frozen soil conditions, infiltration in the soil can be impeded, resulting in greater surface runoff. Underestimations of the total runoff prediction by MIKE SHE, LISEM and HBV can therefore be expected. However, that was only the case for the MIKE SHE and LISEM models (Fig. 7).

The overestimation of total runoff in HBV in periods I and II can be explained by 15 the model parameter BETA, which controls the contribution to runoff from rainfall and snowmelt (Figs. 7 and 8). The BETA parameter is a partitioning of the water flow so instead of increasing the storage of the uppermost soil compartment, the infiltration is redirected to the groundwater compartment. The results show that BETA was set to a substantially high value to create a best fit of runoff dynamics (Bergstrom and Graham, 1998). The high BETA value may account for surface runoff caused by partly frozen soil, even if surface runoff as such is not explicitly represented in the model.

The graphical comparison of observed and predicted hydrographs during autumn (Figs. 5 and 6) and CDF residuals (Figs. 8 and 9) showed that MIKE SHE generally overestimated the discharge peak and total runoff volume. This can be explained by a is the same as leaching coefficient. It is simply a factor to regulate how quickly water can drain from the saturated zone to a recipient node, e.g. in the stream. The general overestimation of most peak discharge volumes by CoupModel in autumn is mainly due to the lower value of actual evapotranspiration used compared with the HBV model.

HESSD

9, 5121-5165, 2012

Usefulness of four hydrological models

Z. Kalantari et al.

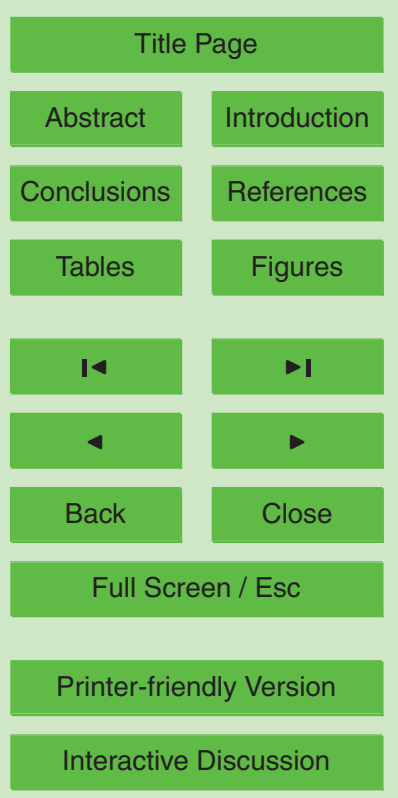

Interactive Discussion 


\section{Discussion}

Our results indicate that outputs from models can differ considerably from measured catchment runoff values. Overall, the timing of simulated and observed peaks matched reasonably well. However, in some cases the simpler HBV model gave better predic5 tion of simulated peak discharge than the more complex model (LISEM, MIKE SHE and CoupModel) when integrating the results from different periods. Regression of the measured and simulated average hourly flow from HBV resulted in an $R^{2}$ value of 0.86 (Table 3), indicating that the model adequately tracked the hourly flow trends during the simulation period. Similarly, the NSE value was calculated to be 0.82 , indicating

10 a good fit (Fig. 3). In general, the results obtained from HBV indicated that the model satisfactorily calculated total runoff during all three periods analysed. Possible reasons behind the better performance of HBV simulation are: (i) the simplicity of HBV model; (ii) the low number of total parameters (17 parameters); and (iii) calibration of the model against all parameters.

\subsection{Runoff simulation during snowmelt}

During the spring snowmelt period, a large amount of water becomes available. As the soil infiltration capacity is limited, all the water cannot infiltrate the soil. Infiltration into soil is controlled mainly by soil porosity and the distribution of liquid and frozen soil moisture. Influenced by snow simulation in period I (Fig. 3), MIKE SHE produced

a slightly earlier peak than the observed discharge. Snowmelt took place earlier and faster in MIKE SHE simulations and therefore led to earlier runoff and higher peak discharge. MIKE SHE also underestimated the total volume of runoff. There are two possible explanations: firstly, there was a smaller amount of estimated snow, hence less total volume of water available for runoff and infiltration; secondly, partially frozen than predicted by MIKE SHE. In period I, the snow simulation had a great impact on

\section{HESSD}

9, 5121-5165, 2012

Usefulness of four hydrological models

Z. Kalantari et al.

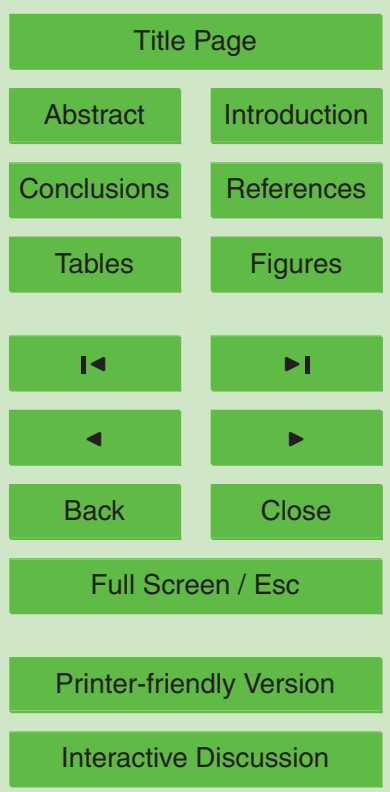

Interactive Discussion 
the performance of runoff simulation. CoupModel and HBV gave good simulations of snow in this period (HBV actually uses the snow module from CoupModel).

\subsection{Runoff simulation during frozen soil conditions}

In addition to snowmelt, the infiltration rate and surface runoff were important here. In 5 frozen and partially frozen soil, the infiltration rate can change due to changes in soil hydraulic conductivity, pore size distribution in soil and soil structure (Hillel, 1998). The models tested in this study did not simulate all these details. For example, CoupModel reduces the infiltration rate based on soil temperature, ice content and soil properties, while MIKE SHE does not change the infiltration capacity even when the soil is frozen.

10 The results indicated that MIKE SHE, CoupModel and HBV, all differing in their frozen soil schemes, overestimated peak discharge during period II (Fig. 5). This can be explained by differences in the parameters used in the calibration process of the different models and a significant impact of evapotranspiration on runoff during autumn.

\subsection{Choice of model for practical applications}

15 To simulate a particular hydrological behaviour of catchments near road structures, choice of appropriate model structure, identifiability of parameter values and minimisation of model analytical uncertainty are vital (Son and Sivapalan, 2007). The appropriate choice of hydrological modelling tools is determined by the type of flood, and also by the length, quality and availability of data records. The chosen model structure must be relatively simple and use parameters that can be identified either from field-measured data or from analysis of catchment response data (Son and Sivapalan, 2007). In the present context, i.e. a basin where a high-quality, real-time monitoring system is available, the HBV model, coupled with CoupModel, appears most suitable. This combination might be best when the calibration data set probably involves the 25 same mechanisms as the validation period. However, changes in e.g. topography and land use cannot be modelled.
HESSD

9, 5121-5165, 2012

Usefulness of four hydrological models

Z. Kalantari et al.

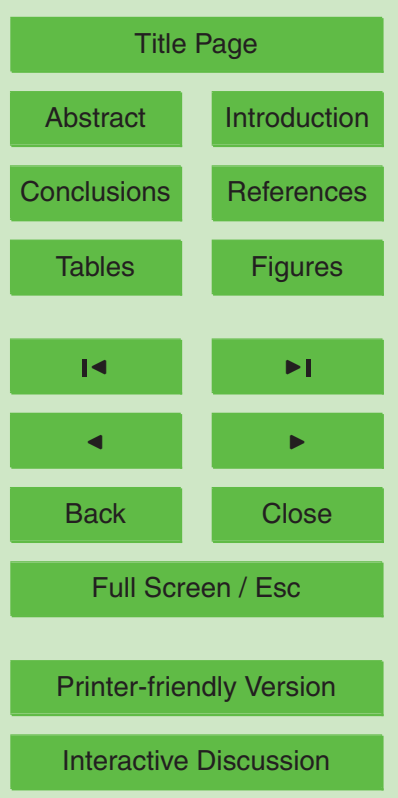

Interactive Discussion 
For ungauged basins with no real-time monitoring of discharge, MIKE SHE can be suitable because of its model structure and less dependency on calibration procedures. For example, in this case study, considering the number of parameters involved in the simulation of the entire hydrological system, and considering the fact that the simple 5 intuitive calibration was done, a reasonable match between the observed and the simulated hydrograph at the catchment outlet could be achieved. However, the accuracy of all models was compromised by the uncertainty in physical parameters and by model structure. MIKE SHE is a flexible modelling system that integrates surface, subsurface and groundwater flow. Due to its capability as a physically-based and fully distributed 10 model, it can be used to evaluate the impacts of alternative land use management practices on watershed response. LISEM is a single-event, physically-based model but it is potentially capable of calculating runoff from a small catchment during winter and spring. The model version used in this study was not completely adapted to the climate region studied. Therefore, modifications to snowmelt, infiltration into frozen layers and 15 tile drainage are required.

The present study covered winter/spring conditions only. Similar comparisons of the models should be conducted for other seasons too. Extreme weather events resulting in high flows can occur at any time of the year in Scandinavia. Those already occurring under the current climatic regime can cause considerable damage to transport

\section{Conclusions}

Changes in climate variables will have effects on watershed hydrological responses and thus influence the amount of runoff reaching transport infrastructures. In view of accelerating climate change, there is a great need for tools such as hydrological models

to quantify these changes and assess their impacts on discharge dynamics, including peak flows. Models used to simulate total runoff in designing road drainage structures

\section{HESSD}

$9,5121-5165,2012$

Usefulness of four hydrological models

Z. Kalantari et al.

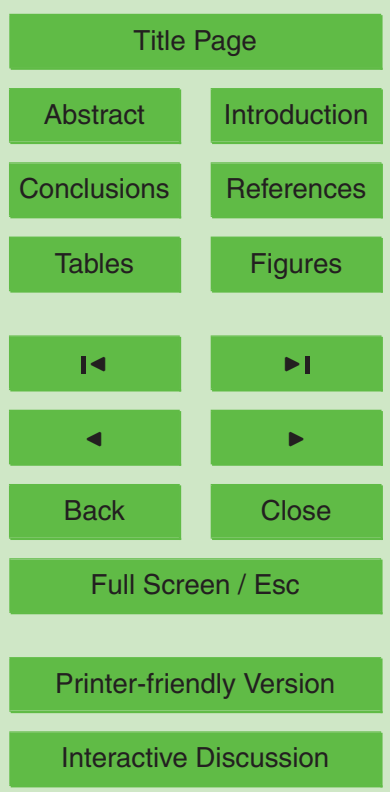

Interactive Discussion 
should take account of periodic hydrological behaviour in the current climate and should also be able to model future climate scenarios.

The hydrological models used in this study should be further evaluated in terms of requirements concerning data and computing resources, difficulties in model setup, 5 calibration and use in order to assess their usefulness in catchments with other characteristics. Some processes, such as those occurring in frozen soil, are not represented in MIKE SHE and LISEM and thus further investigation and calibration are required. However, other parameters may have an implicit ability to represent these processes even though they do not represent the relevant phenomenon.

The calibration procedure and parameter uncertainty were more important than the model structure uncertainty when simulating runoff dynamics from this small watershed with high temporal resolution. However, a model cannot adequately simulate peak discharge and total runoff if the model structure is not capable of representing particular hydrological processes such as overland flow, stream flow, infiltration into soils, evapotranspiration and groundwater flow. On the other hand, the other sorts of uncertainty, for example, meteorological input uncertainty might contribute as well to the discrepancies between observed and simulated discharge.

Acknowledgements. This study forms part of an ongoing collaboration between the "ClimRunoff" project, which is coordinated by Bioforsk in Norway and funded by the Norwegian Research Council, and the "Adaptation of road drainage structures to climate change" project at the Swedish Royal Institute of Technology, conducted within the Centre for Operations and Maintenance and funded by the Swedish Road Administration (now the Swedish Transport Administration).

\section{HESSD}

9, 5121-5165, 2012

Usefulness of four hydrological models

Z. Kalantari et al.

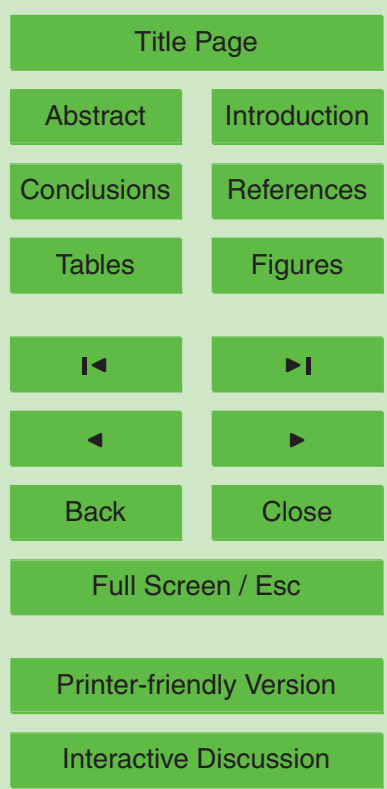




\section{References}

Andersen, J., Refsgaard, J. C., and Jensen, K. H.: Distributed hydrological modelling of the Senegal River Catchment - model construction and validation, J. Hydrol., 247, 200-214, 2001.

5 Bergström, S.: Development and application of a conceptual runoff model for Scandinavian catchments, Ph.D. Thesis, SMHI Reports RHO 7, Norrköping, 1976.

Bergström, S.: The HBV model-its structure and applications, SMHI Reports RH 4, Norrköping, 1992.

Bergstrom, S. and Graham, L. P.: On the scale problem in hydrological modelling, J. Hydrol., 211, 253-265, 1998.

Beven, K. J.: Rainfall-Runoff Modelling, John Wiley \& Sons Ltd., Chichester, 19 pp., 297 pp., 319 pp., 2000.

Beven, K. J.: Rainfall-Runoff Modelling: the Primer, Wiley, West Sussex, England, 360 pp., 2001.

15 Beven, K. J.: A manifesto for the equifinality thesis, J. Hydrol., 320, 18-36, 2006.

Clarke, R. T.: A Review of Some Mathematical Models Used in Hydrology, With Observation on Their Calibration and Use, J. Hydrol., 19, 1-20, 1973.

Dawson, C. W. and Wilby, R. L.: Hydrological modelling using artificial neural Networks, Prog. Phys. Geogr., 25, 80-108, 2001.

20 De Roo, A. P. J., Offermans, R. J. E., and Cremers, N. H. D. T.: LISEM: a single-event physicallybased hydrological and soil erosion model for drainage basins, II. Sensitivity analysis, Hydrol. Process., 10, 1119-1126, 1996.

Deelstra, J., Kværnø, S. H., Skjevdal, R., Vandsemb, S., Eggestad, H. O., and Ludvigsen, G. $\mathrm{H}$.: A general description of the Skuterud catchment. Jordforsk report no. 61/05, Bioforsk,

25 Ås, Norway, 2005.

Deelstra, J., Farkas, C., Engebretsen, A., Kværnø, S., Beldring, S., Olszewska, A. and Nesheim, L.: Can we simulate runoff from agriculture-dominated watersheds? Comparison of the DrainMod, SWAT, HBV, COUP and INCA models applied for the Skuterud catchment, in: Bioforsk FOKUS 5, Modelling of biomass utilization for energy purpose, edited by: Grzybek, 30 A., 119-128, 2010.

DHI: In MIKE-SHE v.5.3 User Guide and Technical Reference Manual, Danish Hydraulic Institute, Denmark, 50, 1998.

\section{HESSD}

9, 5121-5165, 2012

Usefulness of four hydrological models

Z. Kalantari et al.

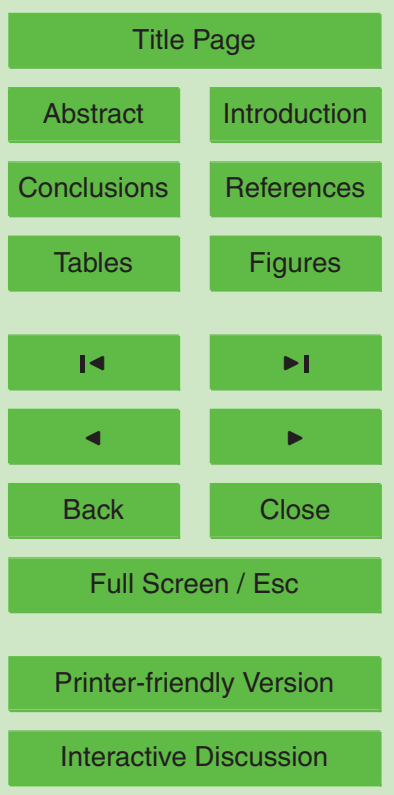

Interactive Discussion 
DHI Software: MIKE SHE - User Manual, DHI Water \& Environment, Hørsholm, Denmark, 2008.

Draper, N. R. and Smith, H.: Applied Regression Analysis, Wiley-Interscience, 1998.

Everitt, B. S.: Cambridge Dictionary of Statistics, 2nd Edn., CUP, 2002.

5 Graham, D. N. and Butts, M. B.: Flexible, integrated watershed modelling with MIKE SHE, in: Watershed Models, edited by: Singh, V. P. and Frevert, D. K., 245-272, 2005.

Green Paper EU: Adapting to climate change in Europe - Options for EU action, Commission of the European Communities, Brussels, 5-17, 2007.

Gurtz, J., Zappa, M., Jasper, K., Lang, H., Verbunt, M., Badoux, A., and Vivar, T.: A comparative study in modelling runoff and its components in two mountainous catchments, Hydrol. Process., 17, 297-311, 2003.

Gustafsson, D., Stähli, M., and Jansson, P.-E.: The surface energy balance of a snow cover: Comparing measurements to two different simulation models, Theor. Appl. Climatol., 70, 8196, 2001.

15 Gustafsson, D., Lewan, E., and Jansson, P.-E.: Modeling water and heat balance of the boreal landscape - Comparison of forest and arable land in Scandinavia, J. Appl. Meteorol., 43, 1750-1767, 2004.

Hayashi, M., van der Kamp, G., and Shmidt, R.: Focused infiltration of snowmelt water in partially frozen soil under small depressions, J. Hydrol., 270, 214-229, 2003.

Hessel, R., Jetten, V., Liu, B., Zhang, Y., and Stolte, J.: Calibration of the LISEM model for a small Loess Plateau catchment, Catena, 54, 235-254, 2003.

Hillel, D.: Environmental Soil Physics. Academic Press, San Diego, USA, 1998.

Jansson, C., Almqvist, E., and Jansson, P.-E.: Heat balance of an asphalt surface: Observations and physically-based simulations, Meteorol. Appl., 13, 203-212, 2006.

Jansson, P.-E. and Karlberg, L.: Coupled heat and mass transfer model for soil-plantatmosphere systems, Royal Institute of Technology, Sweden, 2004.

Jetten, V. and De Roo, A. P. J.: Spatial Analysis of erosion conservation measures with LISEM, Chapter 14, in: Landscape Erosion and Evolution Modeling, edited by: Harmon, R. S. and Doe, W. W., Kluwer Academic/Plenum, New York, 429-445, 2001.

so Jin, X., Xu, C.-Y., Zhang, Q., and Singh, V. P.: Parameter and modeling uncertainty simulated by GLUE and a formal Bayesian method for a conceptual hydrological model, J. Hydrol., 383, 147-155, 2010.

\section{HESSD}

9, 5121-5165, 2012

\section{Usefulness of four hydrological models}

Z. Kalantari et al.

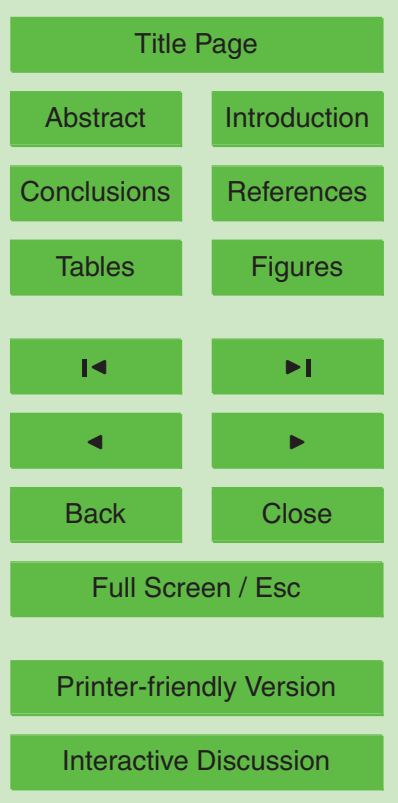

Interactive Discussion 
Kalantari, Z. and Folkeson, L.: Road drainage in Sweden: Current practice and suggestions for adaptation to climate change, Manuscript submitted for publication, 2011.

Kværnø, S. H. and Deelstra, J.: Modelling soil frost and snow dynamics under unstable winter climate, CoupModel simulations in the Skuterud catchment, Jordforsk report no. 37/03, Ås, Norway, 2003.

Kværnø, S. H. and Stolte, J.: Uncertainty in runoff and erosion simulated by the LISEM model, as affected by soil physical properties input data source, submitted to CATENA, 2012.

Kværnø, S. H., Haugen, L. E., and Børresen, T.: Variability in topsoil texture and carbon content within soil map units and its implications in predicting soil water content for optimum workability, Soil Till. Res., 95, 332-347, 2007.

Lindström, G., Johansson, B., Persson, M., Gardelin, M., and Bergström, S.: Development and test of the distributed HBV-96 hydrological model, J. Hydrol., 201, 272-288, 1997.

Loague, K. and Vander Kwaak, J. E.: Simulating hydrologic response for the R-5 catchment: Comparison of two models and the impact of the roads, Hydrol. Process., 16, 1015-1032, 152002.

Maxe, L. and Johansson, P.-O.: Assessing groundwater vulnerability using travel time and specific surface area as indicators, Hydrogeol. J., 6, 441-449, $1998 \mathrm{a}$.

Maxe, L., and Johansson, P.-O.: Bedömning av grundvattnets sårbarhet - Utvecklingsmöjligheter, Assessing groundwater vulnerability - Development potentials,

$20 \quad$ Naturvårdsverket Rapport 4852, Naturvårdsverket, Stockholm, 1998b.

McGechan, M. B., Graham, R., Vinten, A. J. A., Douglas, J. T., and Hooda, P. S.: Parameter selection and testing the soil water simulation model SOIL, J. Hydrol., 195, 312-344, 1997.

Mellander, P.-E., Laudon, H., and Bishop, K.: Modelling variability of snow depths and soil temperatures in Scots pine stands, Agr. Forest Meteorol., 133, 109-118, 2005.

Moriasi, D. N., Arnold, J. G., Van Liew, M. W., Bingner, R. L., Harmel, R. D., and Veith, T. L.: Model evaluation guidelines for systematic quantification of accuracy in watershed simulations, T. ASABE, 50, 885-900, 2007.

Nash, J. E. and Sutcliffe, J. V.: River flow forecasting through conceptual models part I - A discussion of principles, J. Hydrol., 10, 282-290, 1970.

30 Norwegian Meteorological Institute: http://met.no/English/ (last access: April 2012), 2011.

\section{HESSD}

9, 5121-5165, 2012

\section{Usefulness of four hydrological models}

Z. Kalantari et al.

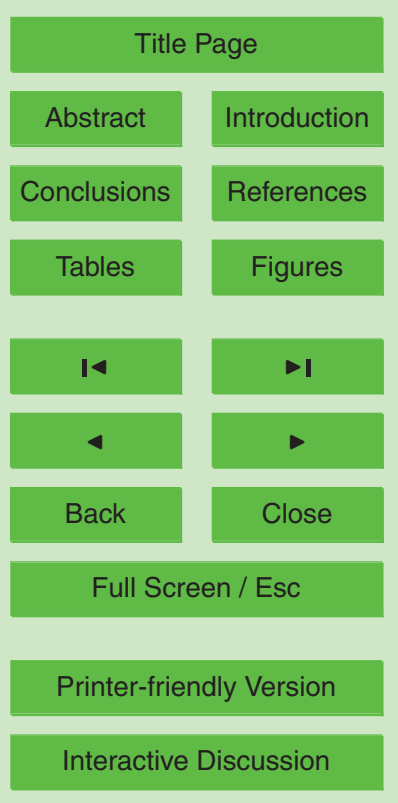


O'Connell, P. E.: A historical perspective, in: Recent advances in modelling of hydrologic systems, NATO ASI Series C: Mathematical and Physical Sciences - Vol. 43, edited by: Bowles, D. S. and O'Connell, P. E., Klewer Academic Publishers, Dordrecht, The Netherlands, 3-30, 1991.

5 Refsgaard, J. C.: Parameterisation, calibration and validation of distributed hydrological models, J. Hydrol., 198, 69-97, 1997.

Saara, A. and Saarenketo, T.: Managing drainage on low volume roads, Executive summary, ROADEX III. The Northern Periphery Research, Oy, Finland, 33-37, 2006.

Sahoo, G. B., Ray, C., and De Carlo, E. H.: Calibration and validation of a physically distributed hydrological model, MIKE SHE, to predict streamflow at high frequency in a flashy mountainous Hawaii stream, J. Hydrol., 327, 94-109, 2006.

Schneider, S. H., Semenov, S., Patwardhan, A., Burton, I., Magadza, C. H. D., Oppenheimer, M., Pittock, A. B., Rahman, A., Smith, J. B., Suarez, A., and Yamin, F.: Assessing key vulnerabilities and the risk from climate change, in: Climate Change 2007: Impacts, adaptation and vulnerability, Contribution of Working Group II to the Fourth Assessment Report of the Intergovernmental Panel on Climate Change (IPCC), edited by: Parry, M. L., Canziani, O. F., Palutikof, J. P., Palutikof, P. J., van der Linden, P. J., and Hanson, C. E., Cambridge University Press, Cambridge, UK, 779-810, 2007.

Silberstein, R. P.: Hydrological models are so good, do we still need data?, Environ. Modell. Softw., 21, 1340-1352, 2006.

Singh, V. P.: Watershed Modeling - Chapter 1, in: Computer Models of Watershed Hydrology, edited by: Singh, V. P., Water Resoures Publications, Colorado, 1-21, 1995.

Son, K. and Sivapalan, M., Improving model structure and reducing parameter uncertainty in conceptual water balance models through the use of auxiliary data, Water Resour. Res., 43, $25 \quad 18$ pp., 2007.

Sorooshian, S. and Gupta, V. K.: Model calibration, in: Computer Models of Watershed Hydrology, edited by: Singh, V. P., Water Resour. Publ. Colorado, 23-68, 1995.

Stähli, M., Nyberg, L., Mellander, P.-E., Jansson, P.-E., and Bishop, K. H.: Soil frost effects on soil water and runoff dynamics along a boreal transect: 2. Simulations, Hydrol. Process., 15, 927-941, 2001.

\section{HESSD}

$9,5121-5165,2012$

\section{Usefulness of four hydrological models}

Z. Kalantari et al.

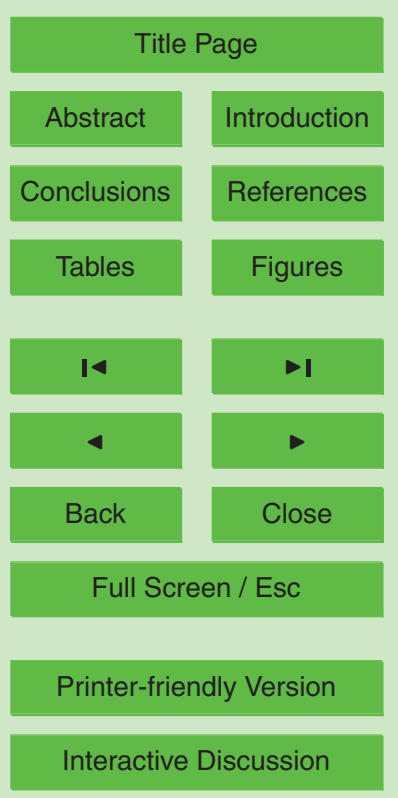


Stejmar Eklund, H.: Hydrogeologiska typmiljöer, Verktyg för bedömning av grundvattenkvalitet, identifiering av grundvattenförekomster samt underlag för riskhantering längs vägar, Licentiate thesis Publ A 101, Geologiska institutionen, Chalmers Tekniska Högskola, Göteborg, 2002.

5 Stolte, J., van Venrooij, B., Zhang, G., Trouwborst, K. O., Liu, G., Ritsema, C. J., and Hessel, R.: Land use induced spatial heterogeneity of soil hydraulic properties on the Loess Plateau, China, Catena, 54, 59-75, 2003.

Stolte, J., Ritsema, C. J., and Bouma, J.: Developing interactive land use scenario's on the Loess Plateau in China, presenting risk analyses and economic impacts, Agr. Ecosyst. Environ., 105, 387-399, 2005.

Tague, C., McMichael, C., Hope, A., and Choate, J.: Application of the RHESSys model to a California semi-arid shrubland catchment, J. Am. Water Resour. Assoc., 40, 575-589, 2004.

Tan, K. S., Chiew, F. H. S., Grayson, R. B., Scanlon, P. J., and Siriwardena, L.: Calibration of a daily rainfall-runoff model to estimate high daily flows, CD-ROM, in: Proceedings of MODSIM 2005, International Congress on Modelling and Simulation, Modelling and Simulation Society of Australia and New Zealand, 2005.

Thue-Hansen, V. and Grimenes, A. A.: Meteorologiske data for Ås 2007-2008, Universitetet for Miljø-og Biovitenskap, Ås, Norway, 2009.

Vásquez, R. F., Feyen, L., Feyen, J., and Refsgaard, J. C.: Effect of grid size on effective parameters and model performance of the MIKE SHE code, Hydrol. Process., 16, 355-372, 2002.

Werner, K., Bosson, E., and Berglund, S.: Description of climate, surface hydrology, and near-surface hydrogeology, Simpevarp 1.2, SKB R-05-04, Svensk Kärnbränslehantering AB, 2005.

Wheater, H. S., Jakeman, A. J., and Beven, K. J.: Progress and directions in rainfall-runoff modeling, in: Modeling change in environmental systems, edited by: Jakeman, A. J., Beck, M. B., and McAleer, M. J., John Wiley \& Sons, UK, 101-132, 1993.

\section{HESSD}

$9,5121-5165,2012$

\section{Usefulness of four hydrological models}

Z. Kalantari et al.

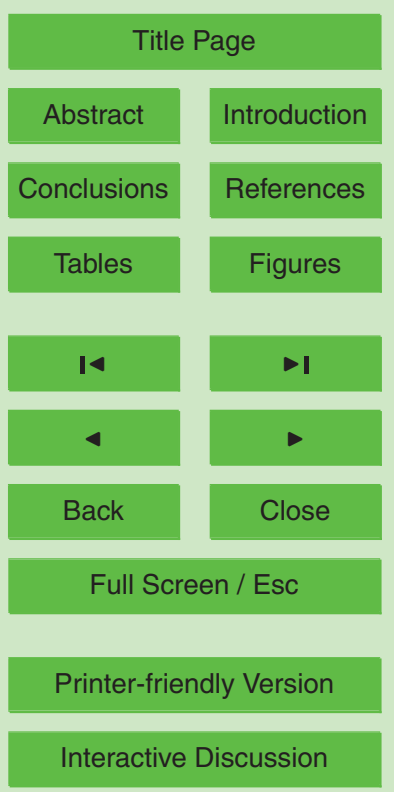


Table 1. Characteristics of LISEM, MIKE SHE, CoupModel and HBV models and their capabilities for various hydrological processes ( $P E T=$ potential evapotranspiration and $\mathrm{ET}=$ evapotranspiration).

\begin{tabular}{|c|c|c|c|c|}
\hline Process & LISEM & MIKE SHE & CoupModel & HBV \\
\hline \multicolumn{5}{|c|}{ Surface water } \\
\hline Evapotranspiration & No & Yes & Yes & Yes \\
\hline Land Use distribution & Yes & Yes & No & No \\
\hline Stream flow & No & Yes & No & No \\
\hline Overland flow & Yes & Yes & Yes & No \\
\hline \multicolumn{5}{|c|}{ Groundwater } \\
\hline Unsaturated flow & Yes & Yes & Yes & Yes \\
\hline Groundwater flow & No & Yes & Yes & Yes \\
\hline Tile drainage & No & Yes & Yes & No \\
\hline \multicolumn{5}{|c|}{ SW/GW interaction } \\
\hline Frozen soil & $\begin{array}{l}\text { Indirect, by altering } \\
\text { the soil infiltration } \\
\text { capacity }\end{array}$ & No & Yes & No \\
\hline Snow melt & Yes & Yes & Yes & Yes \\
\hline Infiltration & Yes & Yes & Yes & Yes \\
\hline \multicolumn{5}{|c|}{ Calibration } \\
\hline Event & Single period & $\begin{array}{l}\text { Entire period, split } \\
\text { period }\end{array}$ & $\begin{array}{l}\text { Entire period, split } \\
\text { period }\end{array}$ & Entire period, split period \\
\hline Method & $\begin{array}{l}\text { Subjective single } \\
\text { parameter }\end{array}$ & $\begin{array}{l}\text { Subjective single } \\
\text { parameter }\end{array}$ & $\begin{array}{l}\text { Subjective multi } \\
\text { parameters }\end{array}$ & Objective multi parameters \\
\hline \multicolumn{5}{|c|}{ Data } \\
\hline $\begin{array}{l}\text { Forcing data } \\
\text { requirements }\end{array}$ & $\begin{array}{l}\text { Meteorological } \\
\text { data such as air } \\
\text { temperature, } \\
\text { precipitation, PET }\end{array}$ & $\begin{array}{l}\text { Meteorological data } \\
\text { such as air temperature, } \\
\text { precipitation, reference } \\
\text { ET }\end{array}$ & $\begin{array}{l}\text { Meteorological data } \\
\text { such as air temperature, } \\
\text { precipitation, explicit } \\
\text { dynamic ET } \\
\text { representation }\end{array}$ & $\begin{array}{l}\text { Meteorological data } \\
\text { such as air temperature, } \\
\text { precipitation, PET }\end{array}$ \\
\hline $\begin{array}{l}\text { Independent input } \\
\text { data }\end{array}$ & $\begin{array}{l}\text { Landscape } \\
\text { data and vertical } \\
\text { distributed input } \\
\text { distributed input } \\
\text { data (soil, } \\
\text { vegetation, } \\
\text { drainage) }\end{array}$ & $\begin{array}{l}\text { Landscape distributed } \\
\text { input data and vertical } \\
\text { distributed input data } \\
\text { (soil, vegetation, } \\
\text { drainage) }\end{array}$ & $\begin{array}{l}\text { Vertical distributed } \\
\text { input data (soil, } \\
\text { vegetation, } \\
\text { drainage) }\end{array}$ & Box-like design (soil data) \\
\hline
\end{tabular}

\section{HESSD}

$9,5121-5165,2012$

\section{Usefulness of four hydrological models}

\section{Z. Kalantari et al.}

Title Page

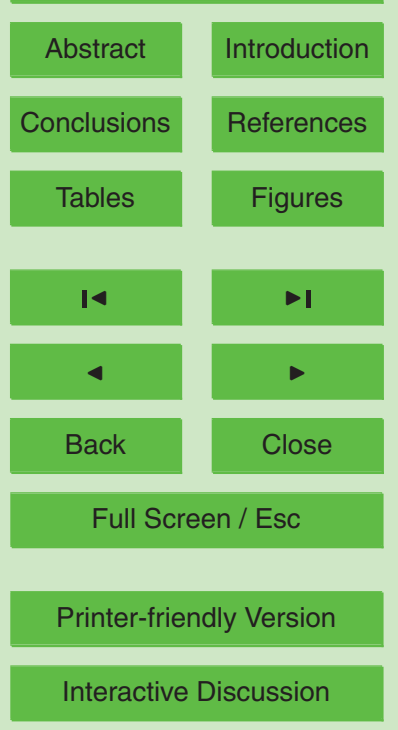


Table 2. LISEM, MIKE SHE, CoupModel and HBV model parameters.

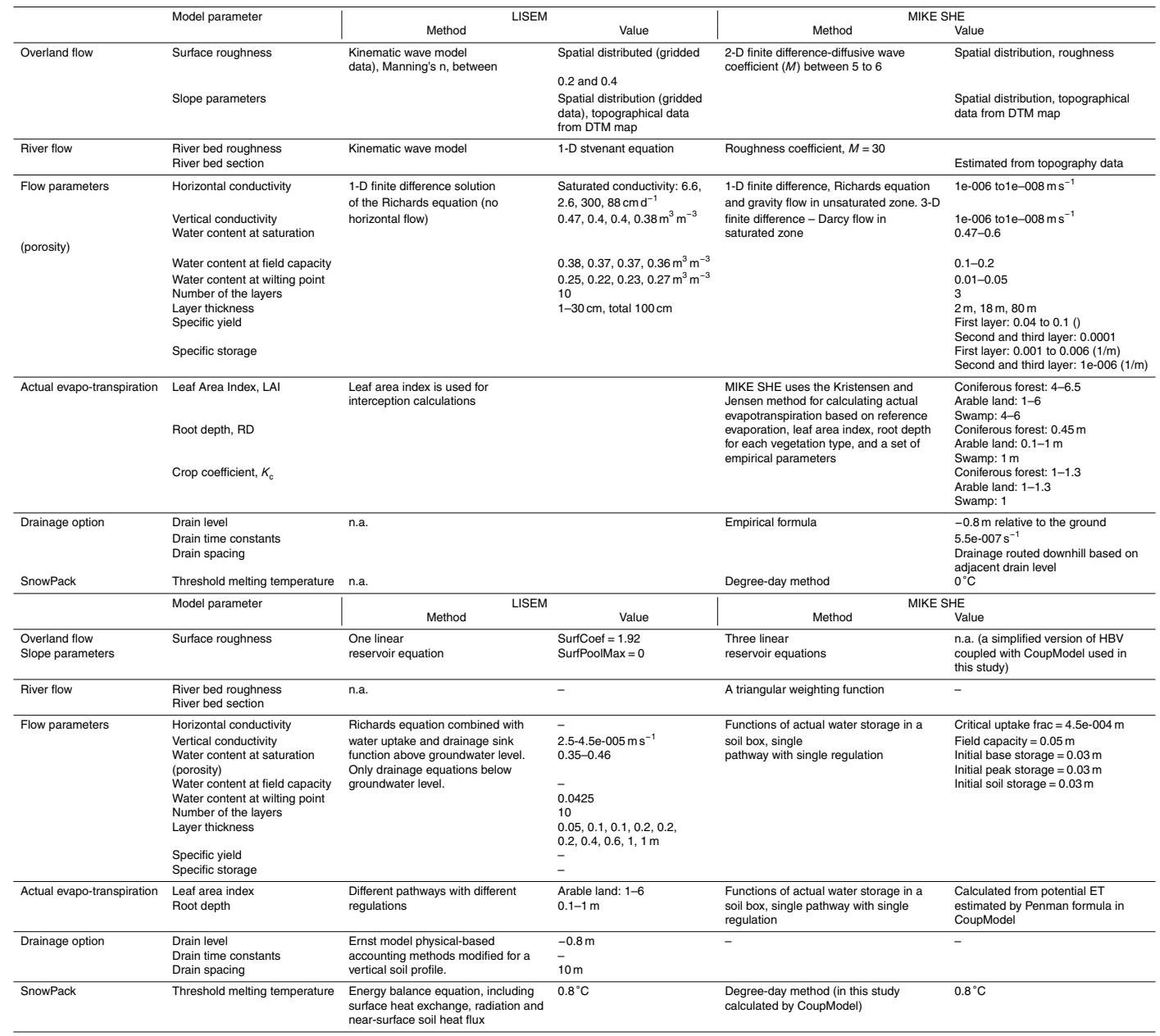

HESSD

$9,5121-5165,2012$

\section{Usefulness of four hydrological models}

Z. Kalantari et al.

Title Page

\begin{tabular}{|c|c|}
\hline Abstract & Introduction \\
\hline Conclusions & References \\
\hline Tables & Figures \\
\hline I4 & \multicolumn{1}{|c|}{} \\
\hline 4 & \\
\hline Back & Close \\
\hline Full Screen / Esc
\end{tabular}

Printer-friendly Version

Interactive Discussion 


\section{HESSD}

9, 5121-5165, 2012

\section{Usefulness of four hydrological models}

Z. Kalantari et al.

Table 3. Statistics of the four models.

\begin{tabular}{lll}
\hline Model & $R^{2, *}$ & NSE $^{* *}$ \\
\hline LISEM & 0.92 & - \\
MIKE SHE (6 months) & 0.75 & 0.52 \\
CoupModel (6 months) & 0.8 & 0.7 \\
HBV (6 months) & 0.86 & 0.82 \\
\hline
\end{tabular}

${ }^{*} R^{2}=$ coefficient of determination, ${ }^{* *} \mathrm{NSE}=$ Nash-Sutcliffe simulation efficiency

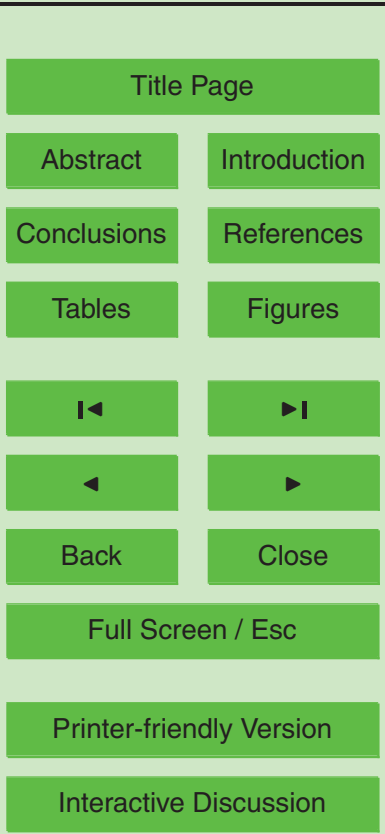




\section{HESSD}

9, 5121-5165, 2012

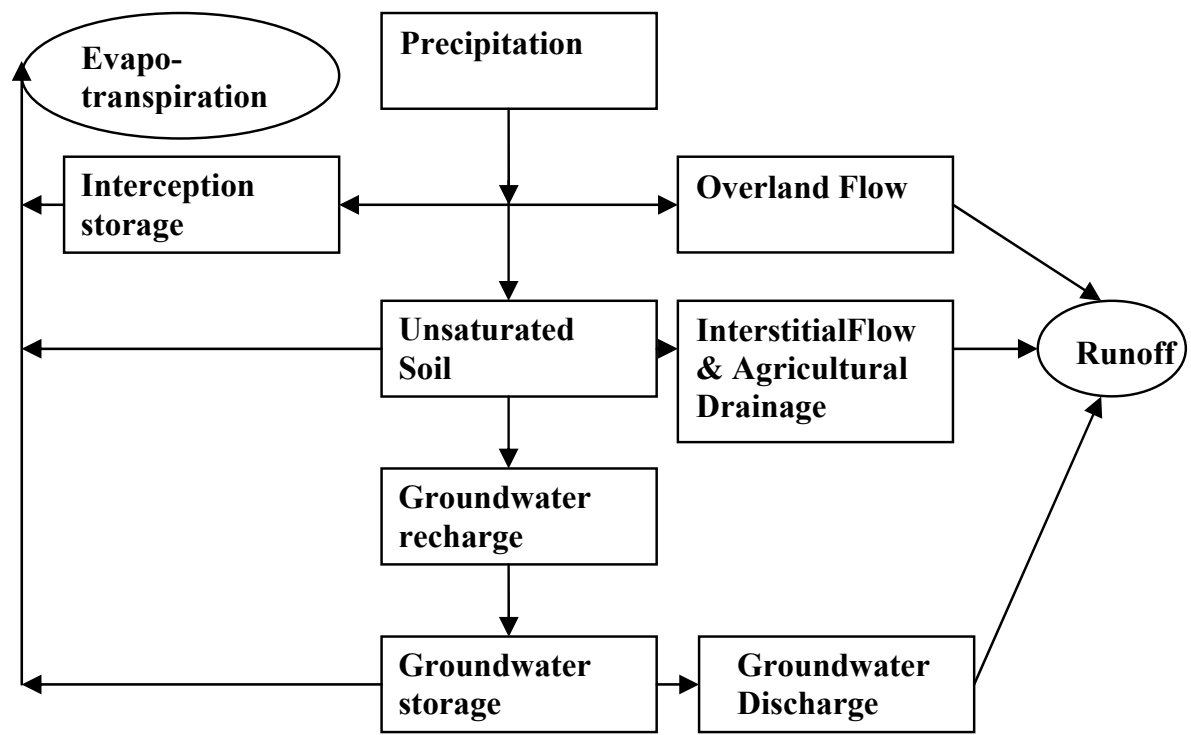

Usefulness of four hydrological models

Z. Kalantari et al.

Title Page

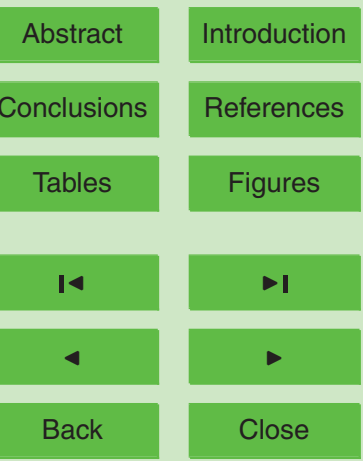

Full Screen / Esc

Printer-friendly Version

Interactive Discussion 


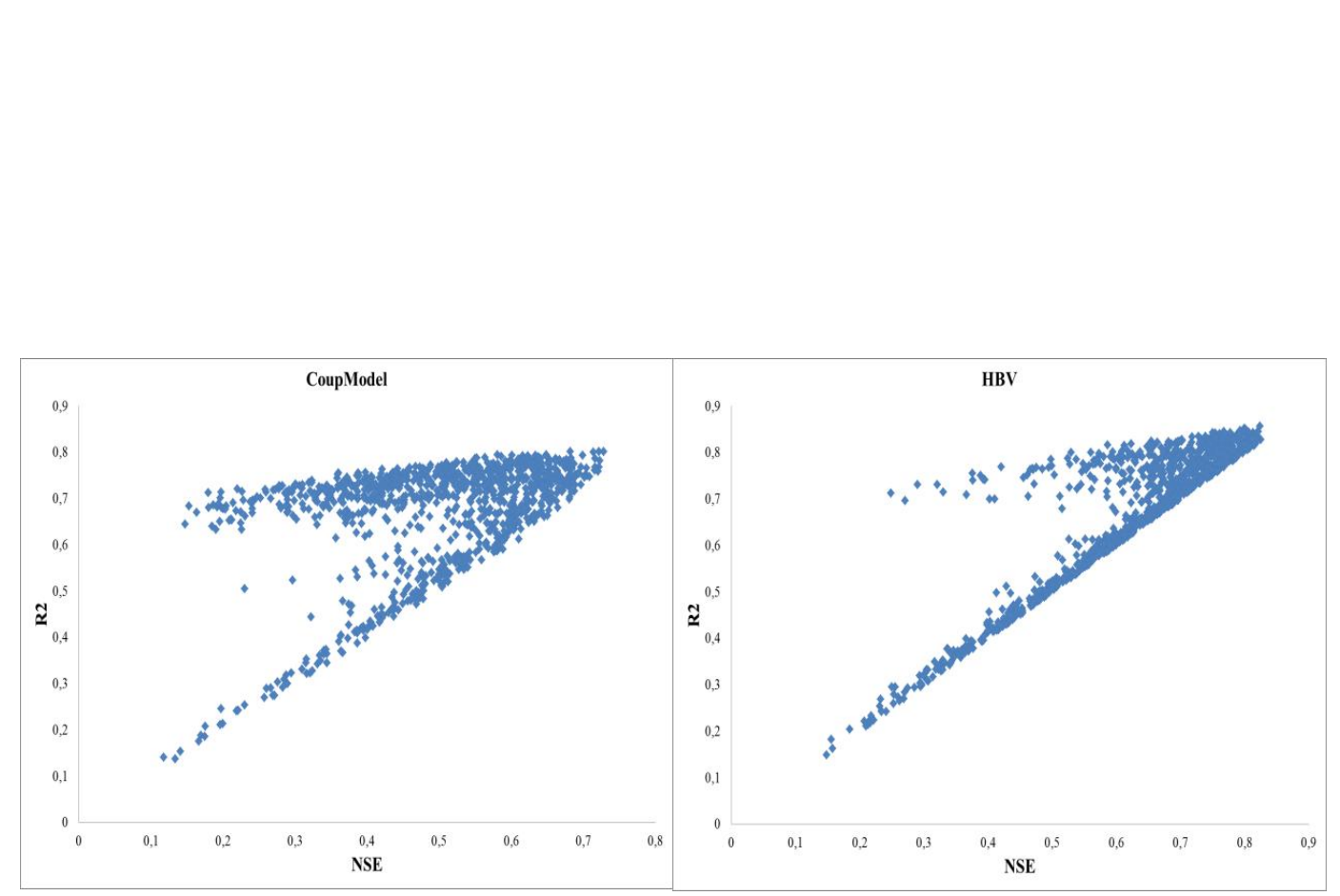

\section{HESSD}

$9,5121-5165,2012$

\section{Usefulness of four hydrological models}

Z. Kalantari et al.

Fig. 2. Scatter of $R^{2}$ (coefficient of determination) and NSE (Nash-Sutcliffe simulation efficiency) for 1000 runs from CoupModel and HBV using data from the Skuterud catchment.

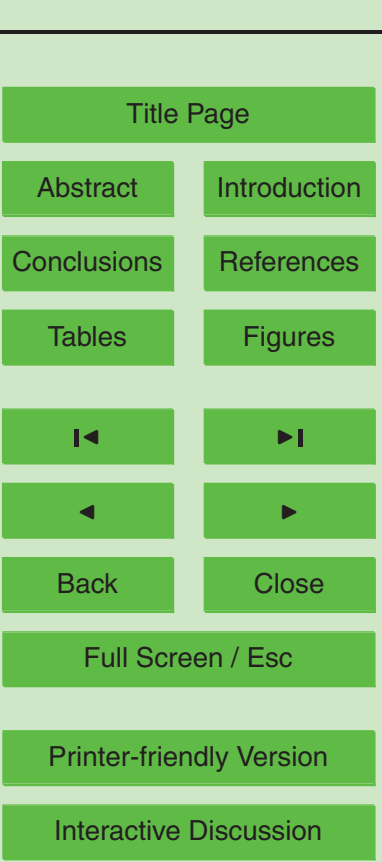




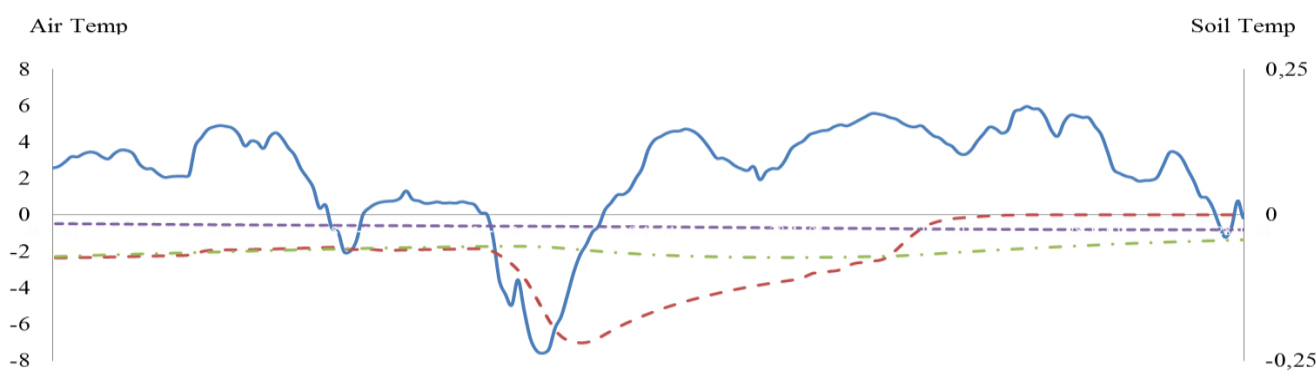

—Air_Temp ${ }^{\circ} \mathrm{C}--$ Soil_Temp ${ }^{\circ} \mathrm{C}(0-5 \mathrm{~cm})--{ }_{-S o i l \_T e m p}{ }^{\circ} \mathrm{C}(5-15 \mathrm{~cm})----S o i l$ Temp ${ }^{\circ} \mathrm{C}(15-25 \mathrm{~cm})$

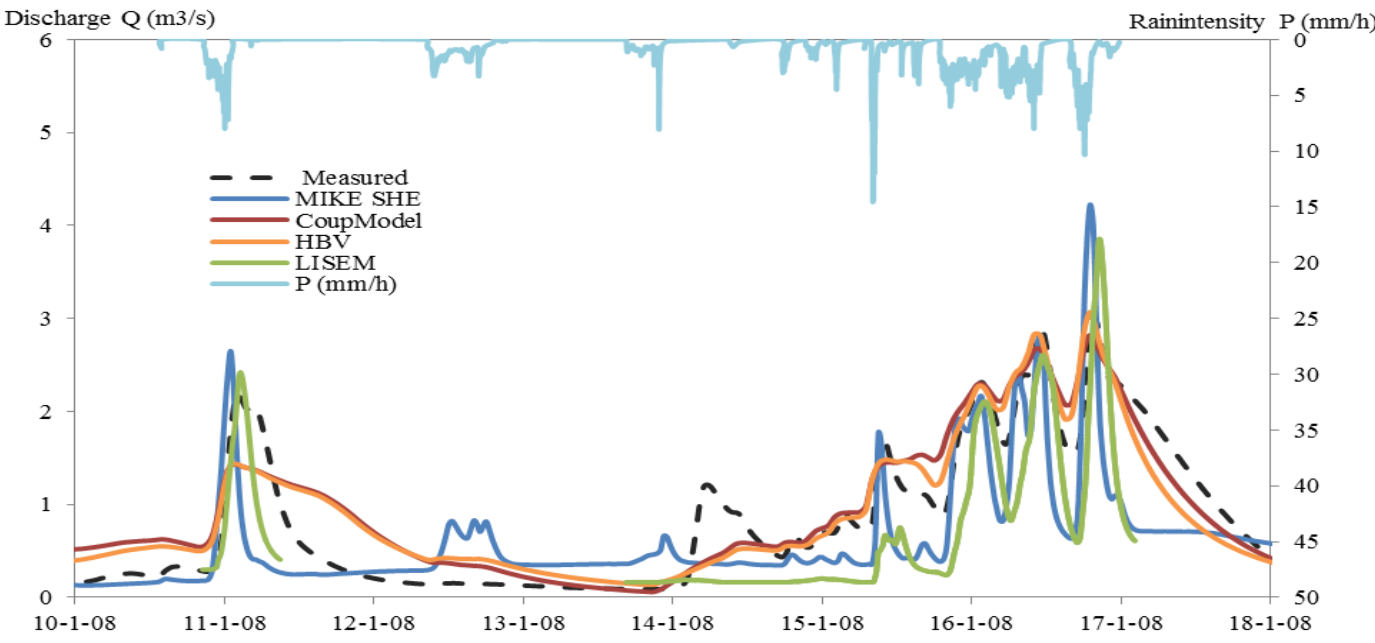

Fig. 3. Temperature, precipitation and measured and simulated discharge during period I. Simulated discharge for MIKE SHE (blue line), CoupModel (red), HBV (orange) and LISEM (green). Measured discharge: black dashed line.

\section{HESSD}

$9,5121-5165,2012$

\section{Usefulness of four hydrological models}

\section{Z. Kalantari et al.}

Title Page

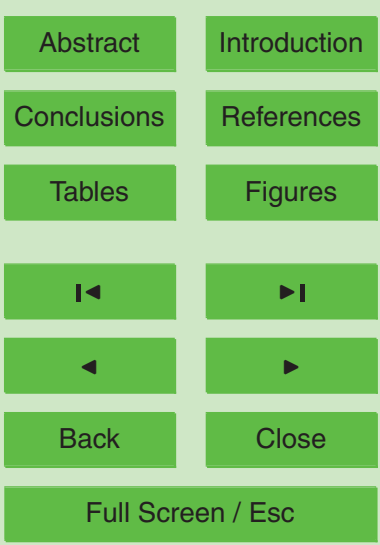

Printer-friendly Version

Interactive Discussion 
HESSD

$9,5121-5165,2012$
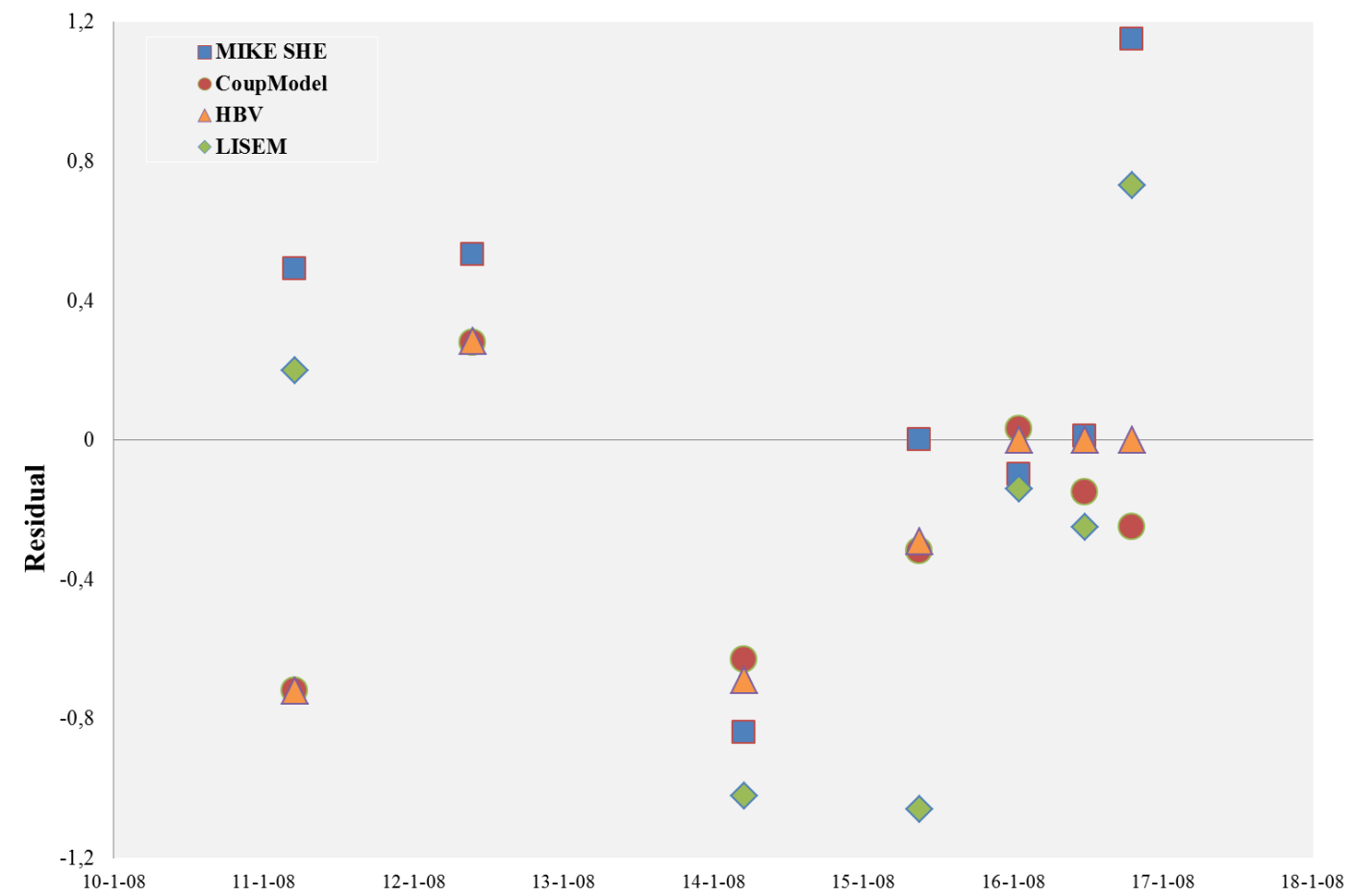

Fig. 4. Peak flow residuals in period I using 4 models: MIKE SHE (blue squares), CoupModel (red circles), HBV (orange triangles) and LISEM (green rhombi).

\section{Usefulness of four hydrological models}

Z. Kalantari et al.

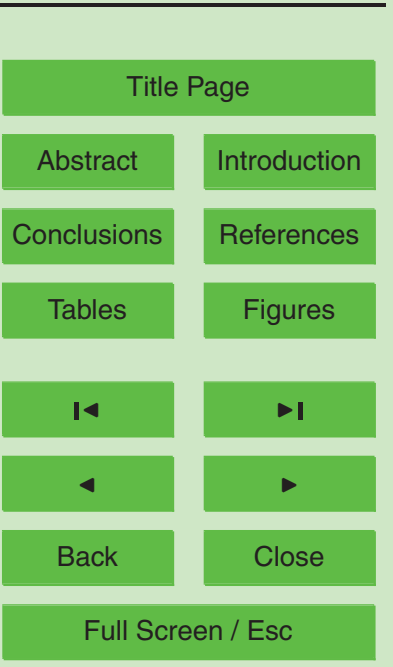

Printer-friendly Version

Interactive Discussion 


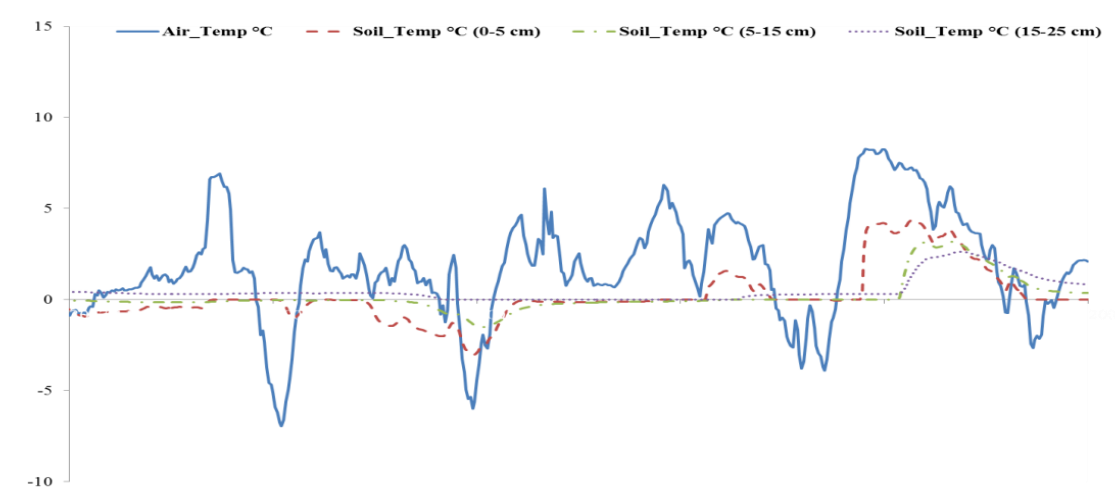

\section{HESSD}

$9,5121-5165,2012$

\section{Usefulness of four hydrological models}

Z. Kalantari et al.

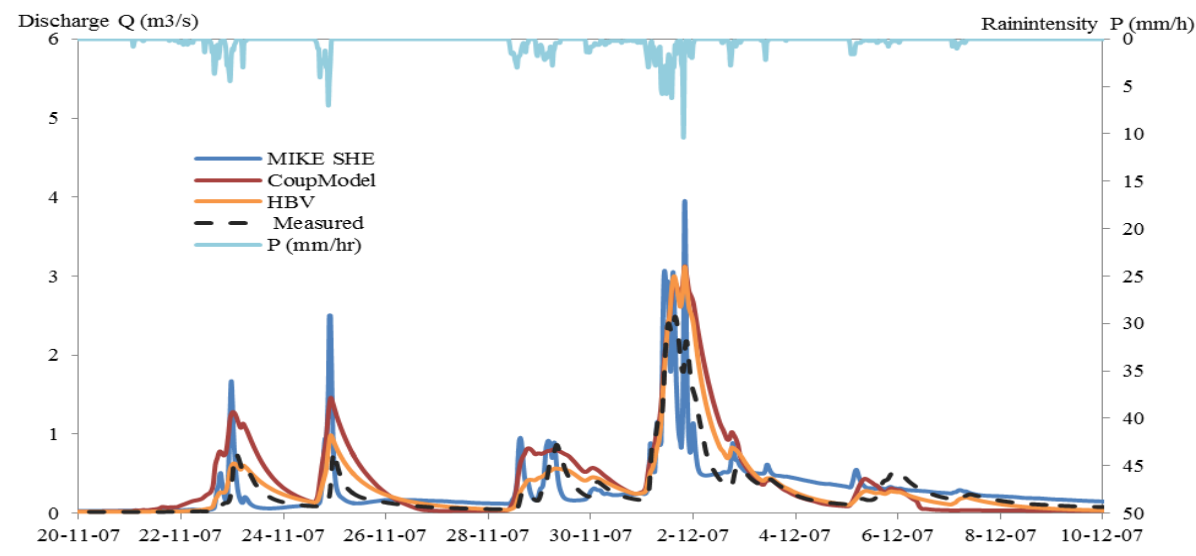

Title Page

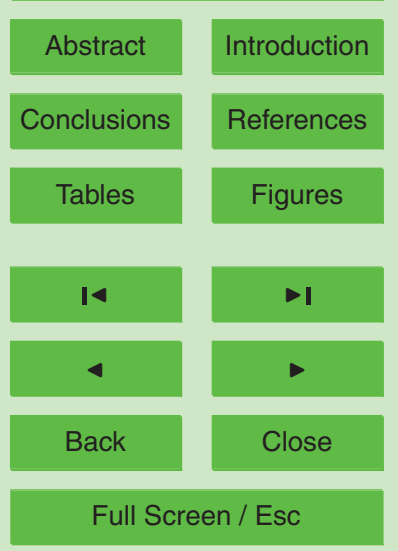

Fig. 5. Temperature, precipitation and measured and simulated discharge during period II. Simulated discharge for MIKE SHE (blue line), CoupModel (red), HBV (orange) and LISEM (green). Measured discharge: black dashed line.

Printer-friendly Version

Interactive Discussion 


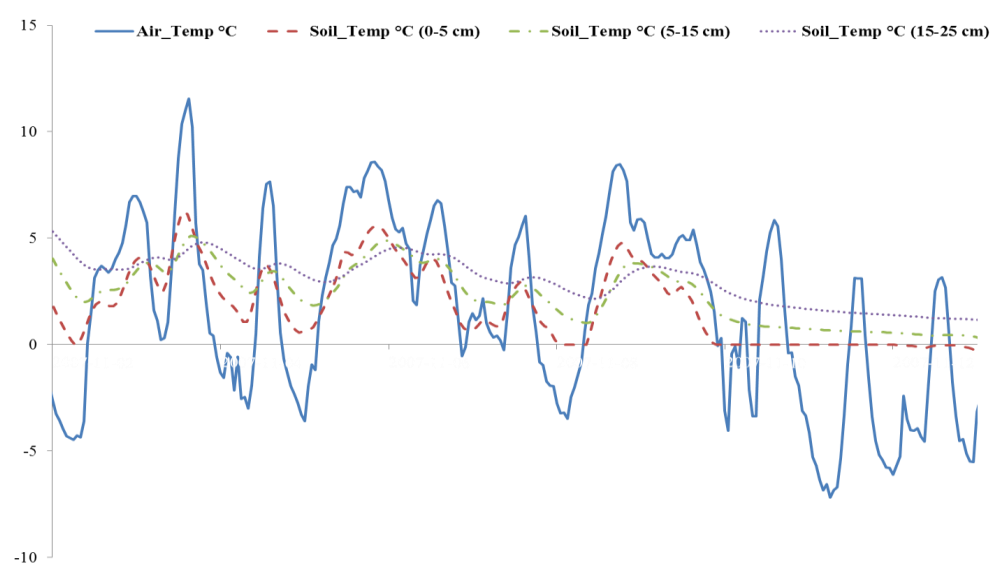

\section{HESSD}

9, 5121-5165, 2012

\section{Usefulness of four hydrological models}

Z. Kalantari et al.
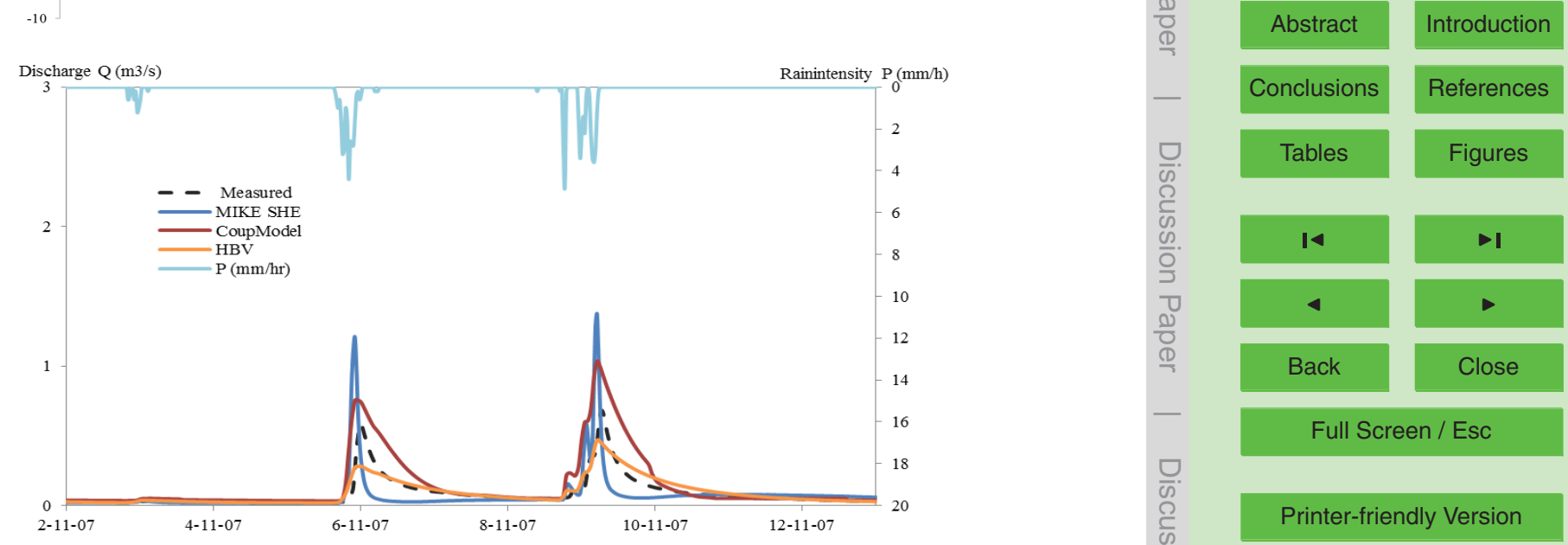

Printer-friendly Version

Fig. 6. Temperature, precipitation and measured and simulated discharge during period III. Simulated discharge for MIKE SHE (blue line), CoupModel (red), HBV (orange) and LISEM (green). Measured discharge: black dashed line.

Interactive Discussion 


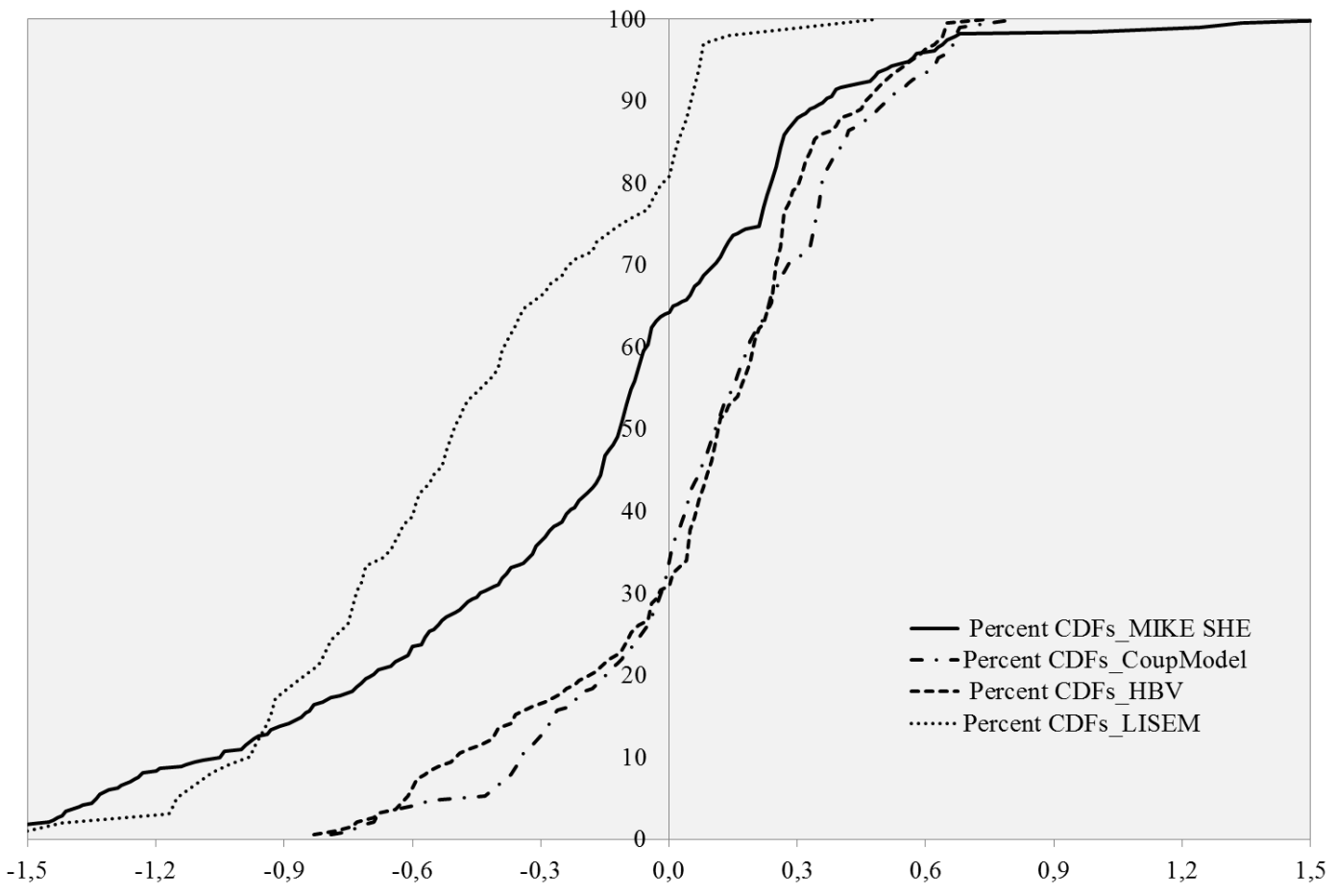

Fig. 7. Percent Cumulative Distribution Functions (CDFs) of residual for the four models: MIKE SHE (black solid line), dashed line CoupModel (dashed line), HBV (dot-dashed line) and LISEM (dotted line) in period I.

\section{HESSD}

$9,5121-5165,2012$

\section{Usefulness of four hydrological models}

Z. Kalantari et al.

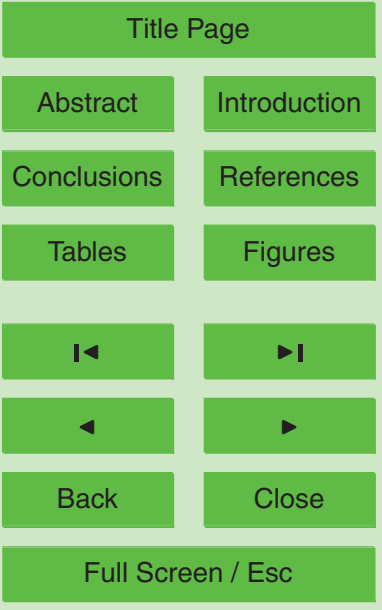

Printer-friendly Version

Interactive Discussion 
HESSD

$9,5121-5165,2012$

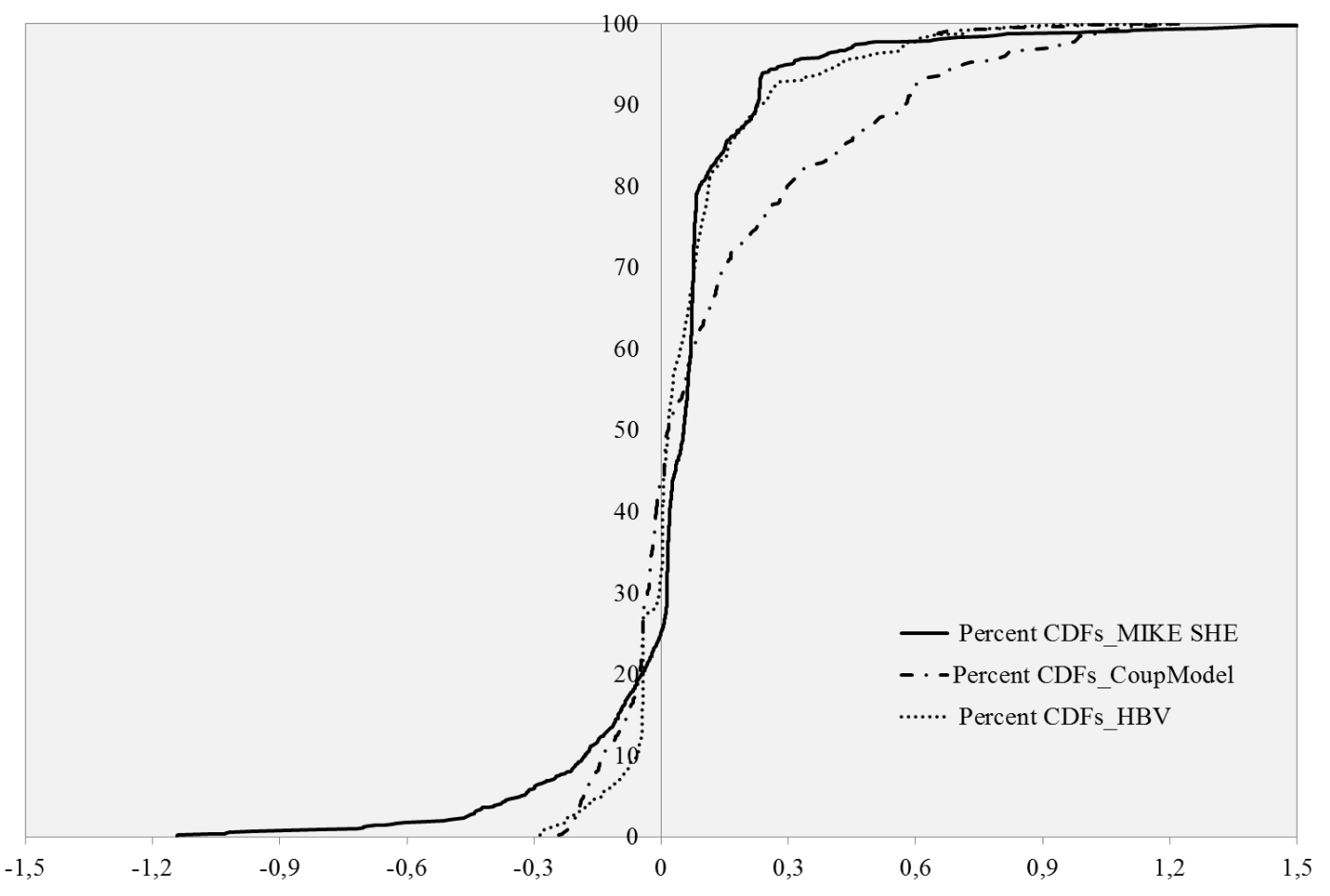

Fig. 8. Percent Cumulative Distribution Functions (CDFs) of residual for the four models: MIKE SHE (black solid line), CoupModel (dashed line) and HBV (dot-dashed line) in period II.

\section{Usefulness of four hydrological models}

Z. Kalantari et al.

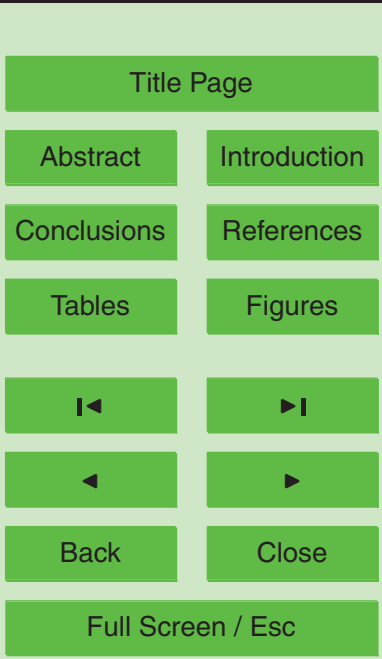

Printer-friendly Version

Interactive Discussion 
HESSD

$9,5121-5165,2012$

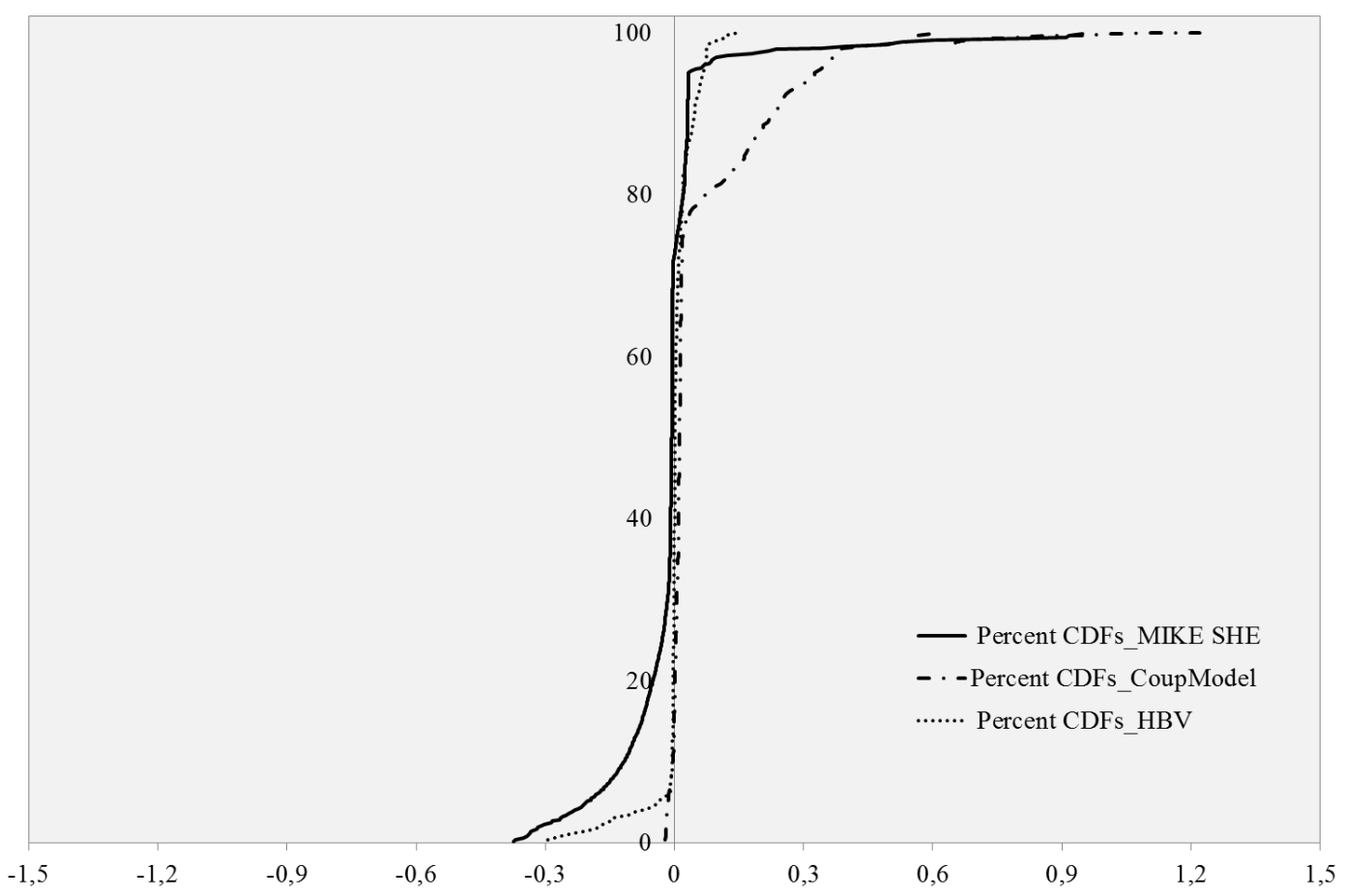

Fig. 9. Percent Cumulative Distribution Functions (CDFs) of residual for the four models: MIKE SHE (black solid line), CoupModel (dashed line) and HBV (dot-dashed line) in period III.

\section{Usefulness of four hydrological models}

Z. Kalantari et al.

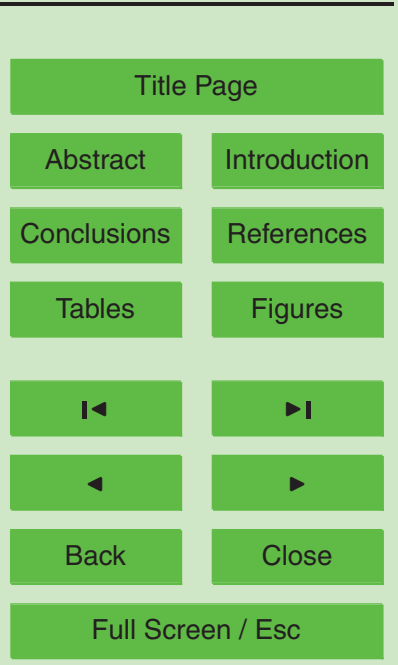

Printer-friendly Version

Interactive Discussion 